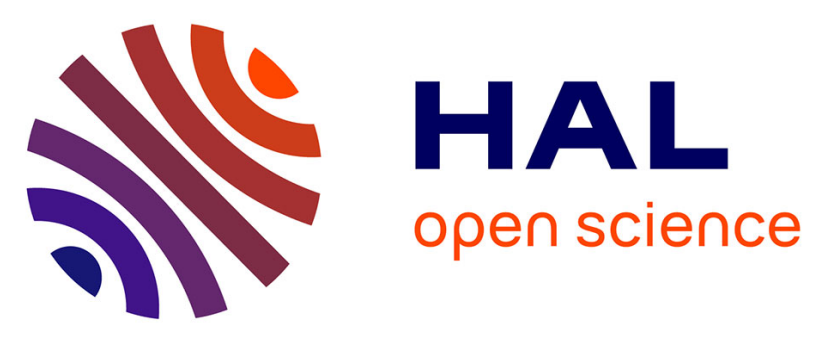

\title{
Relevance of using the non-reactive geochemical signature in sediment core to estimate historical tributary contributions
}

Céline Bégorre, Aymeric Dabrin, Amandine Morereau, Hugo Lepage, Brice Mourier, Matthieu Masson, Frédérique Eyrolle, Marina Coquery

\section{To cite this version:}

Céline Bégorre, Aymeric Dabrin, Amandine Morereau, Hugo Lepage, Brice Mourier, et al.. Relevance of using the non-reactive geochemical signature in sediment core to estimate historical tributary contributions. Journal of Environmental Management, 2021, 292, pp.112775. 10.1016/j.jenvman.2021.112775 . hal-03256295

\section{HAL Id: hal-03256295 \\ https://hal.science/hal-03256295}

Submitted on 31 Aug 2021

HAL is a multi-disciplinary open access archive for the deposit and dissemination of scientific research documents, whether they are published or not. The documents may come from teaching and research institutions in France or abroad, or from public or private research centers.
L'archive ouverte pluridisciplinaire HAL, est destinée au dépôt et à la diffusion de documents scientifiques de niveau recherche, publiés ou non, émanant des établissements d'enseignement et de recherche français ou étrangers, des laboratoires publics ou privés.

\section{(1) (1) $\$$}

Distributed under a Creative Commons Attribution - NonCommercial - NoDerivatives 44.0 
Relevance of using the non-reactive geochemical signature in sediment core to estimate historical tributary contributions

Céline Bégorre ${ }^{\mathrm{a}}$, Aymeric Dabrin ${ }^{\mathrm{a}}$, Amandine Morereau ${ }^{\mathrm{b}}$, Hugo Lepage ${ }^{\mathrm{b}}$, Brice Mourier ${ }^{\mathrm{c}}$, Matthieu Massona $^{\mathrm{a}}$, Frédérique Eyrolle ${ }^{\mathrm{b}}$, Marina Coquery ${ }^{\mathrm{a}}$

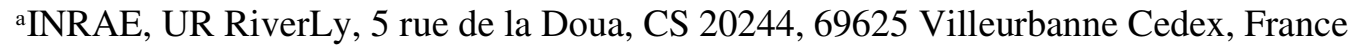

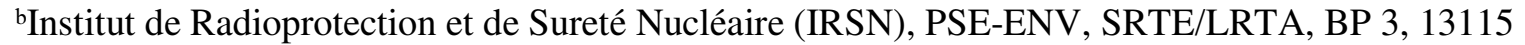

Saint-Paul-lez-Durance, France

'Université de Lyon, UMR5023 LEHNA, Université Lyon 1, ENTPE, CNRS, 3 rue Maurice Audin, 69518 Vaulx-en-Velin, France

Key words: geochemical fingerprinting, sediment core, non-reactive fraction of metals, suspended particulate matter (SPM) 


\section{Highlights:}

Assessment of historical sediment sources with an original fingerprinting approach Apportionment modelling using total and residual concentrations of inorganic elements More tracers available with non-reactive fraction to discern historical SPM sources Total concentrations of tracers lead to inaccurate historical sources apportionment More reliable SPM contribution from Upper Rhône tributaries with residual fraction 


\section{Introduction}

Suspended particulate matter (SPM) is important for biogeochemical cycling and aquatic ecosystem functioning, but it can also have negative impacts on water quality, ecosystems, and the economy (i.e. causing dysfunctions in power plants that use river water, filling reservoirs) (Navratil et al., 2012; Torres-Astorga et al., 2018). Identifying SPM sources can help improve river management to reduce the sediment and associated contaminants load in rivers by implementing remediation actions in source areas. In general, sediment source fingerprinting studies focus on estimating spatial sources of SPM in hydrosystems or on methodological aspects (Walling, 2005; Collins et al., 2017).

Fingerprinting methods for tracing sources of SPM or sediment, which has evolved considerably since the 1970s, employ tracers (Walling, 2013; Collins et al., 2017). Tracer science has also evolved with analytical techniques developed to greatly increase the number of physical, biological, geochemical and other properties that can serve for source tracing (Walling, 2013; Collins et al., 2020). A majority of fingerprinting studies have used geochemical properties as tracers (e.g. trace metals/metalloids, major elements; Collins et al., 2020), which is explained by the inclusion of these properties in the composition of soils and SPM that are typical of each watershed. Thus, these properties provide an effective tool to discriminate the potential sources identified.

As signalled in the review of D'Haen et al. (2012), few studies have focussed on the application of source tracing to sediment cores. However, the historical inputs of SPM from different sources can provide retrospective information on environmental events (floods) or modifications of SPM fluxes, such as dam construction, bank stabilization or revegetation (Collins et al., 1997; Navratil et al., 2012). Dhivert et al. (2016) showed that past anthropogenic inputs were higher for several metals/metalloids (e.g. $\mathrm{Bi}, \mathrm{Cd}, \mathrm{Hg}, \mathrm{As}, \mathrm{Pb}$ ), leading to increased concentrations of some properties in the deepest layers of the core. We therefore deduce that there are differences in concentrations between the sources and the deepest layers of the sediment core, which means that the elements concerned are reactive because the geochemical signature of the deposited SPM has changed over time. Moreover, source fingerprinting in sediment cores does carry some limitations, since total metal concentrations that include anthropogenic inputs and the use of contemporary SPM are commonly used in literature to trace historical sources.

In order to account for the conservatism of tracers in the total fraction, fingerprinting studies generally apply a mass conservation test called the range test (Collins et al., 2017). However, Owens et al. (2016) showed that the range test lacks reliability as some tracers could pass the test yet still have nonconservative behaviour. Moreover, a conservative property could be out of the range of the considered sources, as there might be one unidentified source. Given the challenge of establishing tracer conservativism, using the total concentration of tracers may add uncertainties on the model results due to the reactivity of some of the metals (i.e. including metals and metalloids in the following text). To address this issue, Dabrin et al. (2014) tested the use of trace elements analyzed in the non-reactive 
fraction to trace qualitatively the origin of contemporary SPM from two sources (tributaries) in the highly reactive Gironde estuary. More recently, a similar approach proved useful to trace the SPM contributions of five tributaries on the Upper Rhône River (Dabrin et al., 2021). Furthermore, several studies show that total metal concentrations in sediment have widely varied over the past decades (e.g. Audry et al., 2004; Dhivert et al., 2016), and may be modified as a result of diagenetic processes that occur in the sediment column (D'Haen et al., 2012; Collins et al., 2017). It is therefore essential to ensure the conservativism of properties for tracing SPM sources over a large time-scale (i.e. using sediment cores). Thus, the use of the non-reactive fraction could be advantageous for the application of fingerprinting methods in a multitude of environments (i.e. estuaries, delta, acid mine drainage) and, then, implement management actions aimed at reducing major sediment inputs to rivers.

There are still only few studies focusing on the potential reactivity of metals in the total fraction (Ankers et al., 2003; Carter et al., 2006; Pulley et al., 2015). Pulley et al. (2015) applied the range test to investigate tracer conservatism (i.e. magnetic, radionuclide, and geochemical tracers) in layers of six sediment cores in the Nene River watershed (UK). If some properties failed the range test for some core layers, then the corresponding layers were removed from further analysis (Pulley et al., 2015). This method, advocated by Collins et al (2017), results in the loss of a large amount of information on sources over time, information which may be essential for this type of study. Another limitation in the identification of historical inputs of SPM is the difference in grain size between contemporary SPM sources and sediment core layers. As many metals (i.e. $\mathrm{As}, \mathrm{Cu}, \mathrm{Cd}, \mathrm{Ni}, \mathrm{Co}, \mathrm{Zn}, \mathrm{Pb}$ ) have a strong affinity with fine particles (Horowitz, 1991; Koiter et al., 2015), SPM can have higher concentrations of some metals than the coarser particles deposited in sediment cores. To homogenize the particle size distribution between sediment core layers and source samples (SPM from tributaries or surface soil samples), some studies include a particle size correction of the geochemical concentrations (metals, rare earths and major cations; Manjoro et al., 2017).

Given the methodological limitations to ensuring tracer conservatism, here we set out to: (1) investigate the relevance of using the non-reactive fraction of metals in fingerprinting approaches applied on a sediment core, and (2) assess the historical contributions of SPM inputs in a sediment core collected on the Upper Rhône River, downstream of three major tributaries, using the total and non-reactive fractions. For that purpose, we focussed on historical SPM inputs in the Rhône River basin, which is one of the largest watersheds and the main contributor of SPM to the Mediterranean Sea (Launay, 2014; Zebracki et al., 2015; Delile et al., 2020).

\section{Materials and Methods}

2.1. Study area 
The Rhône River is one of Europe's major rivers and the biggest sediment input to the Mediterranean Sea, with an inter-annual mean of 324 t.km . $^{-2}$ ear $^{-1}$ for the 1994-1995 period (Launay, 2014; UNEP/MAP, 2003). Its watershed covers an area of $95,600 \mathrm{~km}^{2}$ and a wide diversity of geological and climatic conditions (Zebracki et al., 2015; Delile et al., 2020). Since 2010, concentrations and fluxes of SPM and associated contaminants of the Rhône River and its tributaries are monitored and managed under the Rhône Sediment Observatory (OSR) program. A monitoring network up and running since 2009 collects a large set of SPM samples and data, which are freely available from the online database of the OSR (Thollet et al., 2018). Our study focussed on a simplified system on the upper part of the Rhône River catchment $\left(\approx 7000 \mathrm{~km}^{2}\right)$. This area includes three main tributaries located upstream of the sediment core location (Fig. 1), i.e. the Arve, the Fier, and the Guiers Rivers, which have catchment areas of $2164 \mathrm{~km}^{2}, 700 \mathrm{~km}^{2}$ and $614 \mathrm{~km}^{2}$, respectively. The Lake Geneva outlet, located upstream of the Arve River, is considered a negligible source of SPM to the Rhône River, in line with Launay (2014) who reported that Lake Geneva acts as a reservoir for deposited SPM and that the quantities of SPM discharged at its outlet into the Rhône River are negligible. In terms of contributions of each tributary in terms of average SPM fluxes, the Arve, Fier and Guiers Rivers brought 0.49, 0.18 and 0.07 Mt.year-1 respectively, for the period 2001-2011 (Launay, 2014).

\subsection{Sampling strategy}

\subsubsection{Sources sampling}

The SPM samples were collected on the three main tributaries of the Upper Rhône River, the Arve, Fier and Guiers Rivers, which are the potential SPM sources identified in this study (Fig. 1). Each station is located a few kilometres upstream from the confluence with the Rhône River (Thollet et al., 2018). The SPM were collected using particles traps deployed throughout the year and retrieved every month. For the Guiers River, due to repeated vandalism, we had to carry out spot sampling using a continuous centrifuge (Westfalia KA 2-86-76) or by manually sampling large volumes of water. A more detailed description of the sampling methods can be found in Masson et al. (2018). Overall, 22 SPM samples ( $\mathrm{n}=7$ [flood: 3, base water flow: 4] for the Arve River, $\mathrm{n}=15$ [flood: 8, base water flow: 7] for the Fier River, $n=6$ in flood condition for the Guiers River) were collected between 2012 and 2019, and were used to identify the SPM signature of each tributary.

\subsubsection{Targeted sediments: sediment core sampling}

A $101 \mathrm{~cm}$-long sediment core was sampled from a flat-bottom boat with Uwitec gravity corer (including hammer accessory) equipped with a transparent PVC liner (diameter, $90 \mathrm{~mm}$ ). This core was collected in a secondary channel of the Rhône River (close to the sediment core sampled in 2008 by Desmet et al. (2012)) at a point located downstream of the confluence of the Guiers River (45.7034806 N, 5.555225 E), during a low-water period in September 2018 (Fig. 1). This site is always submerged with inflows from the Rhône River downstream and from La Morte River upstream 
(see Morereau et al. (2020) for a detailed description of the sampling area). An apparent 31\% compaction of the sediment core was observed. We identified 25 roughly $4 \mathrm{~cm}$-thick layers and each layer was sub-sampled using a ceramic knife in order to collect from 32.7 to $133.8 \mathrm{~g}$ of wet sediment. A subsample of fresh sediment was stored for particle size analysis. Other sediment subsamples were freeze-dried, grinded and stored in plastic bags until further analytical steps.

2.3. Analysis of trace and major elements in the non-reactive fraction and sediment core dating

The analysis of geochemical properties in SPM and sediment samples involved the quantification of 20 trace and major elements in the total and reactive fraction. The total fraction was determined after triacid mineralization (SI.1). The reactive fraction was obtained by a soft extraction using hydrochloric acid (1 M) at room temperature (Dabrin et al., 2014). The difference between the concentrations of the two fractions gives a so-called 'non-reactive fraction'. Metals were analyzed in both fractions by inductively-coupled plasma optical emission spectroscopy or triple quadrupole inductively-coupled plasma mass spectrometry. Furthermore, samples were analyzed for particle size distribution, according to the method described by Masson et al. (2018), in order to correct the metal concentrations when necessary. More details on analytical methods can be found in the Supplementary material SI 1 and in Dabrin et al. (2014; and 2021).

The sediment core dating using ${ }^{210} \mathrm{~Pb}$ xs $\left({ }^{210} \mathrm{~Pb}\right.$ in excess $)$ and ${ }^{137} \mathrm{Cs}$ concentrations is detailed in the Supplementary material SI 1 (see Morereau et al. (2020) for additional information).

\subsection{Statistical analysis and mixing model}

\subsubsection{Particle size correction of metal concentration data}

Statistical tests (Student's $t$-test or Wilcoxon test) were used to compare SPM particle size distribution between tributaries. As sediment core samples have coarser particles than SPM samples (D'Haen et al., 2012; Huang et al., 2019), it is essential to correct the metal concentration data. Here, despite ongoing debate surrounding this methodological aspect, we applied the particle size correction implemented by Gellis and Noe (2013), which is based on examining the relationship between tracer (metal) concentrations and particle size distribution. If this relation was significant (Pearson's test, $p$ $<0.05$ ), a correction was applied according to equation 1 :

$$
\mathrm{C}_{\mathrm{n}}=\mathrm{C}_{\mathrm{is}}-\left[\left(\mathrm{D}_{50(\mathrm{~S})}-\mathrm{D}_{50(\mathrm{Sed})}\right) \mathrm{x} \mathrm{p}\right] \quad \text { Eq. } 1
$$

where $C_{n}$ is corrected concentration of tracer $i, C_{\text {is }}$ is initial concentration of tracer $i$ in source s, $D_{50(S)}$ is median particle size value of source $\mathrm{s}, \mathrm{D}_{50(\mathrm{Sed})}$ is average $\mathrm{D}_{50}$ value for all target sediment samples, and $\mathrm{p}$ is slope of the regression line. 
To discriminate the three potential SPM sources (the Arve, Fier and Guiers Rivers), we selected tracers via a two-step procedure that included two statistical tests: a Kruskal-Wallis test and a discriminant factor analysis (DFA) (Collins et al., 1997). The range test was performed to test tracer conservatism before the tracer selection step. For this test, tracer concentration in the target sediment (layers of the sediment core) must be within the range of tracer concentrations in the three potential sources (Manjoro et al., 2017; Pulley et al., 2018). We defined the range test from the minimum and maximum values of the concentrations of each source $\left(\mathrm{C}_{\mathrm{is}}\right)$ and the standard deviation (SD) (Eq. 2). To fit the range test, the concentrations in each sediment core layer $\left(\mathrm{C}_{\mathrm{i}}\right)$ must be within the defined limits (Sanisaca et al., 2017).

$\left[\min \left(\mathrm{C}_{\mathrm{is}}\right)\right]_{\text {mean }}-\mathrm{SD} x\left[\min \left(\mathrm{C}_{\mathrm{is}}\right)\right]_{\text {mean }}<\mathrm{C}_{\mathrm{i}}<\left[\max \left(\mathrm{C}_{\mathrm{is}}\right)\right]_{\text {mean }}-\mathrm{SD} x\left[\max \left(\mathrm{C}_{\mathrm{is}}\right)\right]_{\text {mean }} \quad$ Eq. 2

This test eliminates properties for which the concentration in sediment samples is outside the range of the SPM source concentrations. To discriminate the three identified potential sources, we first selected tracers based on the range test using a Kruskal-Wallis test to highlight redundant elements between sources (Collins et al., 2010). Then, the fingerprint properties that showed a significant difference between the three sources $(\mathrm{p}<0.05)$ were tested by DFA to ensure an optimum combination of tracers. Finally, DFA was used to determine the percentage of correctly classified SPM source samples (ideally, 100\% for each source) and the discriminatory power of each tracer. The results are summarized in Table 1.

\subsubsection{Estimation of the source contributions and associated uncertainties}

There are several models for estimating source contributions, but the mixing model combined with Monte Carlo simulation remains the most widely used method in the literature. Here we employed this model to quantify the SPM source contributions, as detailed in Eq. 3:
$\mathrm{C}_{\mathrm{i}}=\sum \sum\left(\mathrm{P}_{\mathrm{s}} \times \mathrm{C}_{\mathrm{is}}\right) / 1000$
Eq. 3

where $\mathrm{P}_{\mathrm{S}}$ is percentage contribution from the SPM tributary s, $\mathrm{C}_{\text {is }}$ is concentration of tracer $\mathrm{i}$ in the tributary $\mathrm{s}, \mathrm{n}$ is number of tributaries, and $\mathrm{C}_{\mathrm{i}}$ is tracer concentration in the target sediment samples (Hughes et al., 2009; Haddadchi et al., 2013). Note that this model is based on two conditions: the source contributions should be between 0 and 1 , and the sum of the contributions is equal to 1 (Hughes et al., 2009; Navratil et al., 2012; Collins et al., 2017).

To estimate the uncertainties associated with modelled contributions, the mixing model was combined with a Monte Carlo analysis. For each target sediment sample (i.e. layers of the sediment core), this analysis provided 1000 model iterations that represent the optimized number of replicates most widely-used in the literature. These iterations are used to determine the mean of the contributions from each source and the associated uncertainty in the form of standard deviation (SD) and 95\% confidence 
intervals (CI95). Some studies also use an estimator of model precision, the mean absolute error (MAE), calculated according to Eq. 4 (Huang et al., 2019):

$$
\text { MAE }=\left\{1-\left(\sum \mid\left[\mathrm{C}_{\mathrm{i}}-\left(\sum \mathrm{P}_{\mathrm{s}} \times \mathrm{C}_{\mathrm{is}}\right)\right] / \mathrm{C}_{\mathrm{i}} / / \mathrm{m}\right\}\right\} \quad \text { Eq. } 4
$$

where $\mathrm{m}$ is number of properties. If the MAF is greater than 0.85 , the model results are reliable.

\section{Results and Discussion}

3.1. Geochemical signature of total and non-reactive fractions of tributary SPM

Geochemical composition of SPM in each source (tributaries) collected between 2012 and 2019 are reported in Fig. 2. The description and comparison of concentrations between tributaries are presented in Supplementary material 3 (SI.3).

Based on the relative proportion of the metals in the non-reactive fraction compared to the total fraction, we determined three mains groups: group 1 (Fig. 2 a) gathers low-reactivity properties (83\%99\% of total fraction, $\mathrm{Al}, \mathrm{Ba}, \mathrm{Cr}, \mathrm{Li}, \mathrm{Ti}$ and $\mathrm{V}$ ), group 2 (Fig. 2 b) gathers moderate-reactivity properties (58\%-78\% of total fraction, $\mathrm{As}, \mathrm{Co}, \mathrm{Fe}, \mathrm{Mg}$ and $\mathrm{Ni}$ ) and group 3 (Fig. $2 \mathrm{c}$ ) gathers highreactivity properties (17\%-46\% of total fraction, $\mathrm{Cd}, \mathrm{Cu}, \mathrm{Zn}, \mathrm{Mn}, \mathrm{Sr}$ and $\mathrm{Pb}$ ). Thus, the use of $\mathrm{Cd}, \mathrm{Cu}$, $\mathrm{Zn}, \mathrm{Mn}, \mathrm{Sr}$ and $\mathrm{Pb}$, which are highly reactive elements, should clearly be avoided for fingerprinting studies as they can decrease the reliability and accuracy of the estimation of source contributions by the models (Laceby et al., 2017; Collins et al., 2017).

First, Al, Ba, Cr, Li, Ti and V (group 1, Fig. 2a) showed only minor differences in concentrations between total and non-reactive fractions. Nonetheless, the reactivity of the properties differs somewhat according to tributary. In the case of $\mathrm{Al}, \mathrm{Cr}$ and $\mathrm{Ti}$, concentrations did not differ significantly (Student's $t$-test and Wilcoxon tests; see SI.2) between the total and non-reactive fractions for the Arve, Fier and Guiers Rivers. Indeed, the differences between the total and non-reactive Al concentrations were lower than $5 \%$ for the three tributaries. For $\mathrm{Cr}$, the total fraction was characterized by approximately $10 \%$ higher concentration values than in the non-reactive fraction for all tributaries. For Ti, calculations showed little difference in concentrations between the two fractions (lower than $2 \%$ for the three tributaries). For $\mathrm{Ba}, \mathrm{Li}$ and $\mathrm{V}$, the differences between the two fractions were significant, but total fraction concentrations were less than $20 \%$ higher than the non-reactive fraction concentrations for all tributaries. These six metals ( $\mathrm{Al}, \mathrm{Ba}, \mathrm{Cr}, \mathrm{Li}, \mathrm{Ti}, \mathrm{V})$ generally had low reactivity in the Rhône tributaries, which is consistent with the literature. For example, aluminium can be used as a reference for calculating the enrichment factor in sediment samples (Ollivier et al., 2011). The enrichment factor reflects the anthropogenic inputs of a given metal in a river system. Given that these anthropogenic inputs have a high reactivity, the enrichment factor could serve as an effective tool for representing the reactive fraction of the SPM. We thus conclude that total $\mathrm{Al}$ concentrations can be 
used in fingerprinting studies in practically any river system. For Ba and V, Ollivier et al. (2011) calculated an enrichment factor of $1.02 \pm 0.16$ and $1.15 \pm 0.12$, respectively, in Rhône River SPM, which means that $\mathrm{Ba}$ and $\mathrm{V}$ have low reactivity.

Second, concentrations of As, $\mathrm{Co}, \mathrm{Fe}, \mathrm{Mg}$ and $\mathrm{Ni}$ (group 2, Fig. 2b) were, in general, significantly higher in the total fraction than in the non-reactive fraction, with differences ranging from $20 \%$ to $45 \%$ depending on focal metal and tributary. This is consistent with results obtained by Ollivier et al. (2011) for Ni analysed in SPM from the Rhône River. Indeed, this study supports its classification as moderate reactivity property (proportion of $70 \%$ of the non-reactive fraction) with an enrichment factor determined as $1.47 \pm 0.3$.

Finally, concentrations of group-3 metals ( $\mathrm{Cd}, \mathrm{Cu}, \mathrm{Mn}, \mathrm{Pb}, \mathrm{Sr}$ and $\mathrm{Zn}$; Fig. 2c) were significantly higher in the total fraction than in the non-reactive fraction. The difference ranged from $50 \%$ to $80 \%$ depending on metal and tributary considered. Ollivier et al. (2011) also studied the reactivity of $\mathrm{Pb}$, among other properties, in the SPM collected at the Arles station, located at the outlet of the Rhône River watershed. The results obtained from the calculation of $\mathrm{Pb}$ enrichment factor (3.89 \pm 1.03$)$ showed that $\mathrm{Pb}$ is influenced by anthropogenic inputs (Ollivier et al., 2011). We therefore conclude that $\mathrm{Pb}$ is not conservative in the total fraction. These studies showed the same trends for $\mathrm{Cd}$ and $\mathrm{Zn}$. Ollivier et al. (2011) calculated enrichment factors of $2.24 \pm 1.08$ for $\mathrm{Cd}$ and $3.32 \pm 0.92$ for $\mathrm{Zn}$, meaning that these two metals are influenced by anthropogenic inputs. $\mathrm{Cd}$ and $\mathrm{Zn}$ are therefore considered non-conservative properties.

\subsection{Historical contamination trends and influence on the non-reactive fraction}

Figure 3 shows the metal concentrations in the two studied fractions as a function of time (from 1984 to 2018) in the sediment core sampled in the Upper Rhône River. Overall, similar sedimentary profiles are observed for metals of group 1 and 2 , for both fractions, with more differences in concentration levels between the two fractions for group 2 (from $37 \%$ to $50 \%$ ) compared to group 1 (from $2 \%$ to $20 \%)$. Properties of group 3 differ from group 1 and group 2 by different temporal trends. Indeed, there are peaks that appear at the top or bottom of the core for the total fraction for metals of group 3 (e.g. $\mathrm{Cd}, \mathrm{Cu}$ and $\mathrm{Zn}$ ). In general, in the total fraction of metals from group 1 and 2, concentrations of $\mathrm{Al}$ (mean of $\left.47.4 \pm 1.7 \mathrm{~g} \mathrm{~kg}^{-1}\right), \mathrm{Ba}\left(249 \pm 10 \mathrm{mg} \mathrm{kg}^{-1}\right), \mathrm{Li}\left(47.1 \pm 2.1 \mathrm{mg} \mathrm{kg}^{-1}\right), \mathrm{V}\left(73.1 \pm 3.1 \mathrm{mg} \mathrm{kg}^{-1}\right)$, As $\left(10.7 \pm 1.3 \mathrm{mg} \mathrm{kg}^{-1}\right)$, Co $\left(12.6 \pm 0.6 \mathrm{mg} \mathrm{kg}^{-1}\right)$, Fe $\left(27.9 \pm 1.5 \mathrm{~g} \mathrm{~kg}^{-1}\right)$ and $\mathrm{Mg}\left(10.9 \pm 0.8 \mathrm{~g} \mathrm{~kg}^{-1}\right) \mathrm{did}$ not show any general decreasing or increasing temporal trend over the study period (1984-2018). For the non-reactive fraction, concentrations of $\mathrm{Al}, \mathrm{Ti}, \mathrm{Ba}, \mathrm{Cr}, \mathrm{Li}$ and $\mathrm{V}$ (group 1) and $\mathrm{As}, \mathrm{Co}, \mathrm{Fe}, \mathrm{Mg}$ and $\mathrm{Ni}$ (group 2) followed a similar trend to total fraction concentrations. On the contrary, $\mathrm{Cd}, \mathrm{Cu}, \mathrm{Pb}, \mathrm{Sr}$ and $\mathrm{Zn}$ (group 3) did not show temporal trends, except for $\mathrm{Cd}$ that tended to decrease from the bottom to the top of the core, but not as much as in the total fraction. 
Another distinctive feature observed on the sedimentary profiles of the total and non-reactive fractions is the presence of a peak of concentration in 1994 for metals of the group-1 and 2 (Fig. 3a and 3b) that is not present for the group-3. These higher concentrations in 1994 may be explained by a generalized flood on the Upper Rhône tributaries in October 1993 and January 1994 (DREAL, 2011). Some of the metals of group 3, such as $\mathrm{Cu}$ and $\mathrm{Zn}$, showed a significant increase in total concentrations in the deepest layers (192 $\mathrm{mg} \mathrm{kg}^{-1}$ and $258 \mathrm{mg} \mathrm{kg}^{-1}$, respectively, in 1987). Cadmium showed three peaks in 1988 (1.13 mg kg-1), $1997\left(0.81 \mathrm{mg} \mathrm{kg}^{-1}\right)$ and 2008 (0.64 $\left.\mathrm{mg} \mathrm{kg}^{-1}\right)$. These concentrations for $\mathrm{Cu}, \mathrm{Zn}$ and $\mathrm{Cd}$ are higher than the geochemical background values (in the order of $0.51-28.8 \mathrm{mg} \mathrm{kg}^{-1}, 11.7$ $116.7 \mathrm{mg} \mathrm{kg}^{-1}$ and 0.05-0.30 mg kg-1 , respectively) reported by Dendeviel et al. (2020) for the Rhône River. Concentrations of $\mathrm{Mn}$ and $\mathrm{Sr}$ showed an increasing trend from 1984 to 2018 with a peak in 2014 and 2016 for Mn (1173 $\mathrm{mg} \mathrm{kg}^{-1}$ and $1204 \mathrm{mg} \mathrm{kg}^{-1}$, respectively) and in 2011 for $\mathrm{Sr}$ (434 $\mathrm{mg} \mathrm{kg}^{-1}$ ). Lead concentrations remained relatively stable, varying by $10 \%\left(25.1 \pm 2.5 \mathrm{mg} \mathrm{kg}^{-1}\right)$ over time with no marked peaks. These values are similar to the $\mathrm{Pb}$ concentrations measured in a sediment core (1965-2007) collected from the same site in 2008 (concentrations between 16 and 28 $\mathrm{mg} \mathrm{kg}^{-1}$; Dendeviel et al., 2020). In contrast, the non-reactive concentrations of Cd $(0.044 \pm 0.033 \mathrm{mg}$ $\left.\mathrm{kg}^{-1}\right), \mathrm{Cu}\left(8.45 \pm 4.28 \mathrm{mg} \mathrm{kg}^{-1}\right), \mathrm{Mn}\left(102 \pm 27 \mathrm{mg} \mathrm{kg}^{-1}\right), \mathrm{Sr}\left(54.7 \pm 13.4 \mathrm{mg} \mathrm{kg}^{-1}\right)$ and $\mathrm{Zn}(38.8 \pm 5.1$ $\mathrm{mg} \mathrm{kg}^{-1}$ ) were low and did not show any peaks (Fig.3c). The non-reactive concentrations were more stable over time compared to total concentrations due to the exclusion of the reactive part of the SPM by $\mathrm{HCl}$ extraction. The notion of conservatism is more important when tracing historical inputs than contemporary SPM sources. A higher reactive fraction proportion of As (50\%), Cd (93\%), Cu (86\%), $\mathrm{Fe}(48 \%), \mathrm{Pb}(86 \%)$ and $\mathrm{Zn}(69 \%)$ was found in sediment core samples than in SPM samples (24\%, $60 \%, 69 \%, 28 \%, 69 \%$ and $55 \%$ for $\mathrm{As}, \mathrm{Cd}, \mathrm{Cu}, \mathrm{Fe}, \mathrm{Pb}$ and $\mathrm{Zn}$, respectively). This is consistent with the literature, which highlights that metals in the sediment core are subject to temporal changes driven by diagenesis and the evolution of contaminants inputs, resulting in peaks in metal concentrations over time (D’Haen et al., 2012; Collins et al., 2017).

Despite this shift of reactivity between SPM and sediment core samples, metals follow the same pattern and agree with the proposed classification according to their low, moderate or high reactivity. For example, for group 1 (Fig. 3a), taking into account all layers of the core, the $\mathrm{Al}$ and $\mathrm{Ti}$ concentrations of the non-reactive fraction accounted on average for $92 \%$ and $98 \%$, respectively, of the total fraction. Similarly, the average proportions of the non-reactive fraction in relation to the total fraction for $\mathrm{Ba}, \mathrm{Cr}, \mathrm{Li}$ and $\mathrm{V}$ range from 80 to $98 \%$ according to metal, and are of the same order of magnitude as what we found in SPM samples. This is consistent with the work of Dendeviel et al. (2020), who determined the natural geochemical background concentrations of some metals in the Upper Rhône River by collecting a sediment core from the pre-industrial period. The measured reference value for $\mathrm{Cr}$, for example, was $63.8 \mathrm{mg} \mathrm{kg}^{-1}$ using total extraction (Dendeviel et al., 2020). Here, the $\mathrm{Cr}$ values calculated in the non-reactive fraction were relatively close to the reference value, 
with an average of $63.7 \pm 5.3 \mathrm{mg} \mathrm{kg}^{-1}$. We thus consider that total $\mathrm{Cr}$ concentrations do not undergo significant anthropogenic inputs.

For As, $\mathrm{Co}, \mathrm{Fe}, \mathrm{Mg}$ and $\mathrm{Ni}$ (Group 2), the average proportion of the non-reactive concentration ranged from $50 \%$ to $60 \%$. These values are similar to those reported in SPM, except for As and Fe that showed higher values in the sediment core. For Fe, this proportion averaged $48 \%$ in the sediment core vs $28 \pm 3 \%$ in SPM for all tributaries. For As, the proportion of the non-reactive fraction for the sediment core samples averaged around 50\% vs 70\%-80\% for the SPM samples, which suggests that As is more reactive in the sediment core than in SPM. This is corroborated by studies from Hung et al. (2009) and Tessier (2015) who highlighted the high reactivity of As under diagenetic conditions. In fact, Smedley and Kinniburg (2002) notably showed that As is associated with Fe and Mn oxides, which are dissolved under reducing conditions releasing As into the interstitial water of the sediment.

Finally, the highly reactive metals such as $\mathrm{Cd}, \mathrm{Cu}, \mathrm{Mn}, \mathrm{Pb}, \mathrm{Sr}$ and $\mathrm{Zn}$ (group 3) showed concentration differences of $70 \%-95 \%$ on average between the total fraction and non-reactive fractions concentrations in the sediment core, following a similar pattern to SPM. In contrast to the observations made for both other groups, not all these metals show the same temporal trend. For example, in the total fraction, $\mathrm{Cd}, \mathrm{Cu}$ and $\mathrm{Zn}$ concentrations increased strongly in the deepest layers (from 1985 to 1988) whereas $\mathrm{Mn}$ and $\mathrm{Sr}$ concentrations were higher in the more recent layers of the core.

Conversely, in the non-reactive fraction, all these properties showed a relatively stable evolution of concentrations along the sedimentary profile. Thus, in the total fraction, the significant differences in concentrations of $\mathrm{Cd}, \mathrm{Cu}, \mathrm{Mn}, \mathrm{Sr}$ and $\mathrm{Zn}$ between the bottom and top of the sediment core suggest metal inputs due to the various anthropogenic pressures over time, whereas the non-reactive fraction helps to reduce the impact of metal reactivity on estimations of source contributions.

3.3. Relevance of the non-reactive fraction to optimize tracer selection

In order to obtain reliable results on SPM source contributions in the Rhône River using the total fraction, it is essential to take into account the conservatism of the tracers and to identify and exclude non-conservative properties from the procedure. This is carried out using the range test (Fig. 4) and can be illustrated by Fig. 2. The results of statistical tests are given in Supplementary Material SI.2, (Table SI.2).

In the total fraction, half of the properties ( $\mathrm{Li}, \mathrm{V}, \mathrm{Co}, \mathrm{Fe}, \mathrm{Cd}, \mathrm{Cu}, \mathrm{Pb}$ and $\mathrm{Zn}$ ) had significantly higher concentrations in sediment core than in SPM samples. This suggests that these metals are more reactive in the sediment core than in SPM samples. Note too that anthropogenic inputs were not the same 40 years ago as in contemporary SPM, which may explain the difference between sources and sediment core for some of these properties $(\mathrm{Cd}, \mathrm{Cu}, \mathrm{Pb}$ and $\mathrm{Zn})$. In contrast, in the non-reactive fraction, only Co, Li and V still had significantly higher concentrations in the sediment core than in SPM samples. In the non-reactive fraction, As had significantly higher concentrations in the SPM of 
the Arve River than in the sediment core, whereas there were no differences between the Fier and Guiers Rivers and sediment core samples. Consequently, the non-reactive fraction increased the number of tracers available for the application of the fingerprinting procedure. These observations can be confirmed by the results of the range test.

The range test was performed for all studied elements in the total and non-reactive fractions by comparing concentrations in the three main SPM sources with concentrations in each of the sediment core layers (see Eq. 2). According to each sediment core layer (Fig. 4), more elements do not satisfy the range test in the total fraction (from 2 to 7 ) than in the non-reactive fraction (from 0 to 3 ), especially in the deepest sediment core layers. All these properties are therefore considered nonconservative and were removed for further analysis. In the total fraction, concentrations of $\mathrm{Co}, \mathrm{Cd}, \mathrm{Li}$ and $\mathrm{V}$ were outside the range of the source values for most of the sediment core layers, which is consistent with results illustrated in Figure 2. For $\mathrm{Cu}, \mathrm{Pb}$ and $\mathrm{Zn}$, only the deepest layers $(63-100 \mathrm{~cm})$ did not meet the range test. These results are consistent with the trends illustrated in Fig. 3 showing an increase in $\mathrm{Cu}$ and $\mathrm{Zn}$ concentrations in the deepest layers. Concentrations of Pb prior to 1997 did not increase as strongly as for $\mathrm{Cu}$ and $\mathrm{Zn}$ but were nevertheless higher than the range of the source values. For Fe and Mn, the superficial layers (first $20 \mathrm{~cm}$ ) of the sediment core had total concentrations outside the range test reflecting the concentration increases seen in recent years (2011-2018 for Fe and 2014-2016 for Mn) (Fig. 3). Finally, as shown in Fig. 3, the 1994 layer features a concentration peak for almost all the metals studied, which can explain why $\mathrm{Al}, \mathrm{Ba}, \mathrm{Cd}, \mathrm{Co}, \mathrm{Cu}, \mathrm{Fe}, \mathrm{Li}, \mathrm{Mg}, \mathrm{Pb}, \mathrm{Ti}$ and V did not pass the range test for the total fraction. In the non-reactive fraction, the number of metals that do not satisfy the range test was significantly lower (Fig. 4). For the deepest layers of the sediment core, there are less metals that are out of the range test for the non-reactive fraction than for the total fraction (Fig. 4). Moreover, for the 1994 layer, there were fewer metals outside the range test with the non-reactive fraction (7) than the total fraction (11). Nonetheless, as suggested in the literature (Collins et al., 2017), we decided to remove the 1994 layer from further methodological steps in order to keep enough tracers for the mixing model. The higher metal concentrations ( $\mathrm{Al}, \mathrm{Ti}, \mathrm{Ba}, \mathrm{Cr}, \mathrm{Li}, \mathrm{V}$, As, $\mathrm{Co}, \mathrm{Fe}, \mathrm{Mg}$ and $\mathrm{Ni}$ ) in this 1994 layer of the sediment core may be explained by the widespread flooding of all three tributaries on the Upper Rhône River. Owens et al. (1999) and Manjoro et al. (2017) signalled that using recent SPM to trace source histories likely introduced uncertainties. During such major flood events, the concentrations of some properties can be much higher than those measured in recent SPM (Fig. 2), so the SPM sources in 1994 are not readily associated with the 2012-2019 SPM used (Owens et al., 1999; Manjoro et al., 2017). Using the non-reactive fraction helped to overcome the issue of the source sampling period in general, but was not sufficient to compensate for such extreme past events.

Hence, considering the total fraction, many properties were removed for the analysis of sediment sources, and some of the selected properties are potentially reactive. There were twice as many 
properties out of the range test for the total fraction compared to the non-reactive fraction (Fig.4). For $\mathrm{As}, \mathrm{Cu}, \mathrm{Pb}, \mathrm{Mn}$ and $\mathrm{Zn}$, the non-reactive fraction was respectively about $49 \%, 14 \%, 14 \%, 16 \%$ and $28 \%$, respectively, of the total fraction in the sediment core. These metals thus have high reactivity in

351

352

353 the total fraction but can still be integrated into the model because they pass the range test. Owens et al. (2016) also highlighted that a non-conservative property could still pass the range test. Based on our range test results, the non-reactive fraction presents a great advantage by increasing the number of tracers available for the study and, thus, reducing the potential reactivity of the tracers.

The total fraction includes geological signature and anthropogenic inputs of the tributaries, while the non-reactive fraction reflects only their geological signature and geochemical background. According to the number of metals available following the range test, using the non-reactive concentrations of $\mathrm{Cu}, \mathrm{Fe}, \mathrm{Mn}, \mathrm{Pb}, \mathrm{V}$ and $\mathrm{Zn}$ is more relevant for source fingerprinting in sediment core than total metal concentrations.

\subsection{Historical SPM source inputs on the Upper Rhône River}

The mixing model results are presented in Fig. 5 showing the tributary source contributions as a function of time along the sediment core (from 1984 to 2018) derived from concentrations of metals in the total and non-reactive fractions. For the layers from 2012 to 2018, the source contributions of each tributary did not differ between the total and non-reactive fractions. For the layers from 1984 to 2004, source contributions were significantly different between total and non-reactive fractions used in the mixing model, which is explained by the use of more reactive metals for total fraction due to higher anthropogenic inputs (Fig. 4) (Dendeviel et al., 2020).

Regarding the uncertainties on the source contributions, the 95\% confidence intervals (CI95; SI.3) were low for both fractions and all tributaries. Another way of presenting the uncertainty associated with these results is to calculate the mean absolute error (MAE), as used by Huang et al. (2019). The MAE values associated to source contributions ranged from 0.88 to 0.95 for total fraction and from 0.90 to 0.99 for the non-reactive fraction for the 1984-2018 period. A Student's $t$-test concluded that the MAE values were significantly higher, meaning that estimations are more reliable, for the nonreactive fraction than for the total fraction.

Our results show that the Arve River was the main SPM source contributor to the Rhône River over the past decade for total fraction for the 2001-2018 period (mean of 52.9 $\pm 7.2 \%$ ) and from 1984 to 2018 for the non-reactive fraction (mean of $61.6 \pm 8.5 \%$ ). Results using the two fractions showed significant differences, i.e. the Fier River contributed significantly more and the Guiers River significantly less for the total fraction compared to the non-reactive fraction. The Fier River had a mean contribution of $45.3 \pm 10.3 \%$ for the total fraction against $22.6 \pm 6.1 \%$ for the non-reactive fraction for the 1984-2018 period, while the Guiers River had a mean contribution of $7.3 \pm 4.8 \%$ for the total fraction against $15.8 \pm 7.4 \%$ for the non-reactive fraction for the same period. The higher 
contributions of the Fier River compared to the Guiers River for the 2016-2020 and 2012 periods reflects the much higher SPM fluxes of the Fier River than the Guiers River (average annual water flow of 0.18 Mt.year ${ }^{-1}$ and 0.07 Mt.year ${ }^{-1}$, respectively, for the 2001-2011 period; Launay, 2014). Due to these differences in model results between the two metal fractions, we further investigated the relevance of our mixing model by comparing the estimated contributions of tributary sources using water flow, flood events (2013-2019) and SPM flux data (2012-2019) depending on the data available in the OSR network database (Thollet et al., 2018) (Fig.5).

Several major hydrological events occurred during the study period that may explain the observed variations in source contributions. For the 1987 period, the estimations via our mixing model using the non-reactive fraction clearly show a main contribution of the Arve River $(60 \pm 16 \%)$ and a lower contribution from the Fier River $(25.5 \pm 17.9 \%)$ for this period. In contrast, the total fraction equally distributed the SPM inputs between the Arve and Fier Rivers ( $46 \pm 21 \%$ and $51 \pm 20 \%$, respectively). Knowing that a major 100-year flood that occurred in 1987 on the Arve watershed (Grand Bornan), with a water flow of $150 \mathrm{~m}^{3} \mathrm{~s}^{-1}$ causing intense erosion of the banks and thus a significant sediment load to the river (DREAL, 2011), this suggests that the contributions of the Arve River were more relevant with the non-reactive fraction.

For the 1990 period, as illustrated in Fig. 5, in the total fraction, the Arve and Fier Rivers displayed similar SPM inputs ( $49 \pm 23 \%$ and $47 \pm 21 \%$, respectively) and the Guiers River had a smaller contribution $(3.3 \pm 12.4 \%)$. In the non-reactive fraction, the Arve River contributed to $75 \pm 18 \%$ of SPM inputs, and the Fier and Guiers Rivers contributed far less (16 $\pm 17 \%$ and $7.9 \pm 14.3 \%$, respectively). This 1990 period recorded a ten-year flood on the three tributaries, with water flows of $643 \mathrm{~m}^{3} \mathrm{~s}^{-1}$ for the Arve River, $700 \mathrm{~m}^{3} \mathrm{~s}^{-1}$ for the Fier River, and $403 \mathrm{~m}^{3} \mathrm{~s}^{-1}$ for the Guiers River (DREAL, 2011; Thollet et al., 2018). Using the available SPM flux data (2015-2019), it is assumed that the average interannual contributions in terms of SPM flux are higher for the Arve River (relative contribution of $65 \%$ ) than the Fier River (26\%), which corroborates that the estimates of contributions using the non-reactive fraction is more relevant than the total fraction.

For the Arve River, the contribution peaks observed in the non-reactive fraction in 2003, 2005, 2011 and 2012 can be explained by dam flushing operations that occurred downstream in 2003 and 2012 (Lepage et al., 2020). For 2005 and 2011, represented by major SPM inputs from the Arve River, a major flood in 2005 with a water flow of $361 \mathrm{~m}^{3} \mathrm{~s}^{-1}$ and two floods in 2011 with discharges of 435 and $395 \mathrm{~m}^{3} \mathrm{~s}^{-1}$ (Thollet et al., 2018), explain the larger contribution of the Arve River.

For the 2010 layer, the main source of SPM was the Arve River, which contributed $45 \pm 22 \%$ and $46 \pm 21 \%$ respectively for the total and non-reactive fractions. This higher contribution from the Arve River, compared with the Fier (39\% and 18\% respectively for the total and non-reactive fraction) and Guiers (17\% and 36\% respectively for the total and non-reactive fraction) contributions was consistent 
with the water flow data (with a maximum of $504 \mathrm{~m}^{3} \mathrm{~s}^{-1}$ ) and SPM fluxes. The annual SPM fluxes represent relative contributions of $65 \%, 26 \%$ and $9 \%$ of SPM respectively for the Arve, Fier and Guiers Rivers for the 2001-2011 period. In 2010, for the non-reactive fraction, there was also a higher contribution of the Guiers River (36 $\pm 21 \%$ ) than the Fier River (18 $\pm 16 \%)$. For this period, a 10-year flood occurred on the Guiers River with a maximum water flow of $157 \mathrm{~m}^{3} \mathrm{~s}^{-1}$. The Fier River was also subject to a 100-year flood $\left(505 \mathrm{~m}^{3} \mathrm{~s}^{-1}\right)$. Given that coarser particles deposit faster, we suppose that following the Guiers flood, a majority of these coarse particles would have settled and been deposited downstream. Furthermore, the Guiers River has a particle size distribution substantially closer to the grain size of the sediment core, unlike the Fier River, which could further explain the greater contribution of the Guiers River. For the non-reactive fraction, during the period from 2014 to 2016, there was another peak in the contributions of the Guiers River that could be explained by numerous large floods (about 14 floods with a water flow exceeding $100 \mathrm{~m}^{3} \mathrm{~s}^{-1}$ ) that occurred during this period.

Using the total fraction, our mixing model results show lower contributions for the Arve River than for the non-reactive fraction. According to the hydrological data, our results suggest that the use of the non-reactive fraction is more relevant to estimate source contributions compared to the total fraction. Thus, the use of this non-reactive fraction holds promising potential for the application of sediment fingerprinting. Indeed, using tracers of the total fraction, the tracer selection step can lead to a set of properties that are reactive or characterized by different concentrations between the deepest layers of the core and the contemporary SPM. Arsenic is the most illustrative example, since non-reactive concentrations in the sediment core represent only $49 \%$ of total concentrations, compared to $76 \%$ for contemporary SPM.

\section{Conclusion}

In this study, we used the non-reactive concentrations of metal implemented in a mixing model with a Monte Carlo simulation to estimate historical source contributions in the Upper Rhône River. The results showed that the non-reactive fraction of metals has clear advantages over the total fraction in tracing historical SPM sources through our model. First, for the range test, the non-reactive fraction allows to obtain a greater number of available metals before Kruskal-Wallis test and DFA, and ensures that concentrations of the most reactive metals (i.e. $\mathrm{Cd}, \mathrm{Cu}, \mathrm{Mn}, \mathrm{Pb}, \mathrm{Sr}$ and $\mathrm{Zn}$ ) are conservative (i.e. relatively stable and homogeneous concentrations along the sediment profile). Historical SPM contributions modelling showed that using tracers in the non-reactive fraction was more consistent with historical floods and flow data, and with higher MAE (mean absolute error) values than the total fraction, meaning that uncertainties associated with source contributions for the non-reactive fraction were lower and therefore the results were more reliable. In addition, the use of total concentrations of reactive metals could induce unreliable results. Indeed, some of the selected tracers according to the range test were showed to be highly reactive. According to the results of the non-reactive fraction, the 
SPM from the Arve River mainly constituted the SPM deposited in the Upper Rhône River from 1984 to 2018 , which was relevant to hydrological data. Thus, our study demonstrated that the non-reactive fraction of metal tracers used in fingerprinting studies can be used in a variety of environmental conditions and at various spatial and temporal scales to provide a robust quantification of sediment sources. Moreover, we believe that the non-reactive fraction might also be more effective than the total fraction in tracing the historical SPM sources in a sediment core collected at the outlet of the Rhône River watershed as undertaken in further studies. Since deposited sediments were subject to changes in physicochemical conditions caused by the salinity gradient and to diagenetic processes, which may alter total metal concentrations, the non-reactive fraction may be a more effective tool in fingerprinting studies than the total fraction.

\section{Acknowledgements}

This study was supported by the Rhône Sediment Observatory (OSR), a multi-partner research program partly funded by the 'Plan Rhône' and by the European Regional Development Fund (ERDF). We thank the partner organizations that provided data to the OSR database especially for this study: CNR (Compagnie Nationale du Rhône), FOEN (Federal Office of the Environment, Switzerland), Grand Lyon city council, Veolia, DREAL (the French hydrological agency), and EDF (Electricité de France). This study is also part of the ArcheoRhône project, which was funded by the Water Agency Rhone Mediterranean and Corsica / ZABR (Zone Atelier du Basin du Rhône). We thank our INRAE colleagues Lysiane Dherret, Ghislaine Grisot, Alexandra Gruat, Loïc Richard, Mickaël Lagouy, and Fabien Thollet for their invaluable assistance with SPM sampling, field campaigns, sample treatment and analyses, and Yoann Copard (Université de Rouen) for his help with COP analysis on the sediment core.

\section{References}

Ankers, C., Walling, D.E., Smith, R.P., 2003. The influence of catchment characteristics on suspended sediment properties. Hydrobiologia 494, 159-167. DOI: 10.1023/A:1025458114068

Appleby, P.G., 1998. Dating recent sediments by ${ }^{210} \mathrm{~Pb}$ : problems and solutions. Stuk A-145, 7-24

Audry, S., Schäfer, J., Blanc, G., Jouanneau, J.M., 2004. Fifty-year sedimentary record of heavy metal pollution $(\mathrm{Cd}, \mathrm{Zn}, \mathrm{Cu}, \mathrm{Pb})$ in the Lot River reservoirs (France). Environmental Pollution 132, 413-426. DOI:10.1016/j.envpol.2004.05.025 
BDOH. Thollet, F., Le Bescond, C., Lagouy, M., Gruat A., Grisot, G., Le Coz, J., Coquery, M., Lepage, H., Gairoard, S., Gattacceca, J.C., Ambrosi, J.-P., Radakovitch, O., 2018. Observatoire des Sédiments du Rhône, INRAE. https://dx.doi.org/10.17180/OBS.OSR

Carter, J., Walling, D.E., Owens, P.N., Leeks, G.J.L., 2006. Spatial and temporal variability in the concentration and speciation of metals in suspended sediment transported by the River Aire, Yorkshire, UK. Hydrological Processes 20, 3007-3027. DOI: 10.1002/hyp.6156

Collins, A.L., Walling, D.E., Leeks, G.J.L., 1997. Use of the geochemical record preserved in floodplain deposits to reconstruct recent changes in river basin sediment sources. Geomorphology 19, 151-167. DOI: 10.1016/S0169-555X(96)00044-X

Collins, A.L., Zhang, Y., Walling, D.E., Grenfell, S.E., Smith, P., 2010. Tracing sediment loss from eroding farm tracks using a geochemical fingerprinting procedure combining local and genetic algorithm optimisation. Science of the Total Environment 408, 5461-5471. DOI: 10.1016/j.scitotenv.2010.07.066

Collins, A.L., Pulley, S., Foster, I.D.L., Gellis, A., Porto, P., Horowitz, A.J., 2017. Sediment source fingerprinting as an aid to catchment management: A review of the current state of knowledge and a methodological decision-tree for end-users. Journal of Environmental Management 194, 86-108.

DOI: $10.1016 /$ j.jenvman.2016.09.075

Collins, A.L., Blackwell, M., Boeckx, P., Chivers, C.A., Emelko, M., Evrard, O., Foster, I., Gellis, A., Gholami; H., Granger, S., Harris, P., Horowitz, A.J., Laceby, J.P., Martinez-Carreras, N., Minella, J., Mol, L., Nosrati, K., Pulley, S., Silins, U., da Silva, Y.J., Stone, M., Tiecher, T., Upadhayay, H.R., Yusheng Zhang, Y., 2020. Sediment source fingerprinting: benchmarking recent outputs, remaining challenges and emerging themes. Journal of Soils and Sediments. DOI: 10.1007/s11368-020-02755-4

Copard, Y., Eyrolle, F., Radakovitch, O., Poirel, A., Raimbault, P., Gairoard, S., Di-Giovanni, C., 2018. Badlands as a hot spot of petrogenic contribution to riverine particulate organic carbon to the Gulf of Lion (NW Mediterranean Sea). Earth Surface Processes and Landforms 43, 2495-2509. DOI: 10.1002/esp.4409

Dabrin, A., Schäfer, J., Bertrand, O., Masson, M., Blanc, G., 2014. Origin of suspended matter and sediment inferred from the residual metal fraction: Application to the Marennes Oleron Bay, France. Continental Shelf Research 72, 119-130. DOI: 10.1016/j.csr.2013.07.008

Delile, H., Masson, M., Miège, C., Le Coz, J., Poulier, G., Le Bescond, C., Radakovitch, O., Coquery, M., 2020. Hydro-climatic drivers of land-based organic and inorganic micropollutant fluxes: the regime of the largest river water inflow of the Mediterranean Sea. Water Research 185, 116067. DOI: 10.1016/j.watres.2020.116067 

Bedell, J.P., 2020. Metal pollution trajectories and mixture risk assessment along a major European river since the 1960s (Rhône River, France). Environment International 144, 106032.

Desmet, M., Mourier, B., Mahler, B., Van Metre, P.C., Roux, G., Persat, H., Lefèvre, I., Peretti, A., Chapron, E., Simonneau, A., Miège, C., Babut, M., 2012. Spatial and temporal trends in PCBs in sediment along the lower Rhône River, France. Science of the Total Environment 433, 189-197. DOI:10.1016/j.scitotenv.2012.06.044

D’Haen, K., Verstraeten, G., Degryse, P., 2012. Fingerprinting historical fluvial sediment fluxes.

Dhivert, E., Grosbois, C., Courtin-Nomade, A., Bourrain, X., Desmet, M., 2016. Dynamics of metallic contaminants at a basin scale - Spatial and temporal reconstruction from four sediment cores (Loire fluvial system, France). Science of the Total Environment 541, 1504-1515. DOI: 10.1016/j.scitotenv.2015.09.146

DREAL, 2011. Evaluation préliminaire des risques d'inondation sur le bassin Rhône-MéditerranéePartie IV: Unité de présentation "Haut-Rhône". 42 p. (In French).

533 Gellis, A.C., Noe, G.B., 2013. Sediment source analysis in the Linganore Creek watershed, Maryland, 534 USA, using the sediment fingerprinting approach: 2008 to 2010. Journal of Soils and Sediments 13, 1735-1753. DOI: 10.1007/s11368-013-0771-6

536 Haddadchi, A., Ryder, D.S., Evrard, O., Olley, J., 2013. Sediment fingerprinting in fluvial systems: 537 review of tracers, sediment sources and mixing models. International Journal of Sediment Research 28, 560-578. DOI: 10.1016/S1001-6279(14)60013-5

539 Horowitz, A.J., 1991. A primer on Sediment-Trace Element Chemistry, $2^{\text {nd }}$ Edition. United States 540 Geological Survey 91-76. 142. DOI: 10.3133/ofr9176

541 Huang, D., Du, P., Walling, D.E., Ning, D., Wei, X., Liu, B., Wang, J., 2019. Using reservoir deposits

542 to reconstruct the impact of recent changes in land management on sediment yield and sediment

543 sources for a small catchment in the Black Soil region of Northeast China. Geoderma 343, 139-154.

544 DOI: $10.1016 /$ j.geoderma.2019.02.014

545 Hughes, A.O., Olley, J.M., Croke, J.C., McKergow, L.A., 2009. Sediment source changes over the last 546250 years in a dry-tropical catchment, central Queensland, Australia. Geomorphology 104, 262-275. 
Hung, J.J., Lu, C.C., Huh, C.A., Liu, J.T., 2009. Geochemical controls on distributions and speciation

549

550

551

552

553

554

555

556

557

558

559

560

561

562

563

564

565

566

567

568

569

570

571

572

573

574

575

576

577

578

579 of As and $\mathrm{Hg}$ in sediments along the Gaoping (Kaoping) Estuary-Canyon system off southwestern Taiwan. Journal of Marine Systems 76, 479-495. DOI: 10.1016/j.jmarsys.2008.03.022

ISO, 1995. ISO 10694, Soil quality - Determination of organic and total carbon after dry combustion (elementary analysis).

ISO, 2009. ISO 13320, Particle size analysis - Laser diffraction methods.

Koiter, A.J., Owens, P.N., Petticrew, E.L., Lobb, D.A., 2015. The role of gravel channel beds on the particle size and organic matter selectivity of transported fine-grained sediment: implications for sediment fingerprinting and biogeochemical flux research. Journal of Soils and Sediments 15, 21742188. DOI: $10.1007 / \mathrm{s} 11368-015-1203-6$

Laceby, J.P., Evrard, O., Smith, H.G., Blake, W.H., Olley, J.M., Minella, J.P.G., Owens, P.N., 2017. The challenges and opportunities of addressing particle size effects in sediment source fingerprinting: A review. Earth-Science Reviews 169, 85-103. DOI: 10.1016/j.earscirev.2017.04.009

Launay, M., 2014. Flux de matières en suspension, de mercure et de PCB particulaires dans le Rhône, du Léman à la Méditerranée. (Doctoral dissertation), Université Claude Bernard - Lyon I. (In French).

Lepage, H., Launay, M., Le Coz, J., Angot, H., Miège, C., Gairoard, S., Radakovitch, O., Coquery, M., 2020. Impact of dam flushing operations on sediment dynamics and quality in the upper Rhône River, France. Journal of Environmental Management 255, 109886. DOI:

10.1016/j.jenvman.2019.109886

Manjoro, M., Rowntree, K., Kakembo, V., Foster, I., Collins, A.L., 2017. Use of sediment source fingerprinting to assess the role of subsurface erosion in the supply of fine sediment in a degraded catchment in the Eastern Cape, South Africa. Journal of Environmental Management 194, 27-41. DOI: 10.1016/j.jenvman.2016.07.019

Masson, M., Angot, H., Le Bescond, C., Launay, M., Dabrin, A., Miège, C., Le Coz, J., Coquery, M., 2018. Sampling of suspended particulate matter using particle traps in the Rhône River: Relevance and representativeness for the monitoring of contaminants. Science of the Total Environment 637-638, 538-549. DOI: 10.1016/j.scitotenv.2018.04.343

Morereau, A., Lepage, H., Claval, D., Cossonnet, C., Ambrosi, J.P., Mourier, B., Winiarski, T., Copard, Y., Eyrolle, F., 2020. Trajectories of technogenic tritium in the Rhône River (France). Journal of Environmental Radioactivity 223-224, 106370. DOI: 10.1016/j.jenvrad.2020.106370

Navratil, O., Evrard, O., Esteves, M., Ayrault, S., Lefèvre, I., Legout, C., Reyss, J.L., Gratiot, N., Nemery, J., Mathys, N., Poirel, A., Bonté, P., 2012. Core-derived historical records of suspended 
sediment origin in a mesoscale mountainous catchment: the River Bléone, French Alps. Journal of Soils and Sediments 12, 1463-1478. DOI: 10.1007/s11368-012-0565-2

Ollivier, P., Radakovitch, O., Hamelin, B., 2011. Major and trace element partition and fluxes in the Rhône River. Chemical Geology 285, 15-31. DOI:10.1016/j.chemgeo.2011.02.011

Owens, P.N., Walling, D.E., Leeks, G.J.L., 1999. Use of floodplain sediment cores to investigate recent historical changes in overbank sedimentation rates and sediment sources in the catchment of the River Ouse, Yorkshire, UK. CATENA 36, 21-47. DOI: 10.1016/S0341-8162(99)00010-7

Owens, P.N., Blake, W.H., Gaspar, L., Gateuille, D., Koiter, A.J., Lobb, D.A., Petticrew, E.L., Reiffarth, D.G., Smith, H.G., Woodward, J.C., 2016. Fingerprinting and tracing the sources of soils and sediments: Earth and ocean science, geoarchaeological, forensic, and human health applications. Earth-Science Reviews 162, 1-23. DOI: 10.1016/j.earscirev.2016.08.012.

Pulley, S., Foster, I., Antunes, P., 2015. The application of sediment fingerprinting to floodplain and lake sediment cores: assumptions and uncertainties evaluated through case studies in the Nene Basin, UK. Journal of Soils and Sediments 15, 2132-2154. DOI: 10.1007/s11368-015-1136-0

Pulley, S., Van der Waal, B., Rowntree, K., Collins, A.L. 2018. Colour as reliable tracer to identify the sources of historically deposited flood bench sediment in the Transkei, South Africa: A comparison with mineral magnetic tracers before and after hydrogen peroxide pre-treatment. CATENA 160, 242251. DOI: $10.1016 /$ j.catena.2017.09.018

Sanisaca, L.E.G., Gellis, A.C., Lorenz, D.L., 2017. Determining the sources of fine-grained sediment using the Sediment Source Assessment Tool (Sed-SAT). U. S. Geological Survey 2017-1062, 116. DOI: $10.3133 /$ ofr20171062

Smedley, P.L., Kinniburgh, D.G., 2002. A review of the source, behaviour and distribution of arsenic in natural waters. Applied Geochemistry 17, 517-568. DOI: 10.1016/S0883-2927(02)00018-5

Tessier, E., 2015. Diagnostic de la contamination sédimentaire par les métaux/métalloïdes dans la rade de Toulon et mécanismes contrôlant leur mobilité. (Doctoral dissertation), Université de Toulon. (In French).

Torres Astorga, R., de los Santos Villalobos, S., Velasco, H., Domínguez-Quintero, O., Pereira Cardoso, R., Meigikos dos Anjos, R., Diawara, Y., Dercon, G., Mabit, L., 2018. Exploring innovative techniques for identifying geochemical elements as fingerprints of sediment sources in an agricultural catchment of Argentina affected by soil erosion. Environmental Science and Pollution Research 25, 20868-20879. https://doi.org/10.1007/s11356-018-2154-4

UNEP/MAP., 2003. Riverine transport of water, sediments and pollutants to the Mediterranean Sea. MAP Technical Reports Series 141, 121 p. 
613 Walling, D.E., 2005. Tracing suspended sediment sources in catchments and river systems. Science of 614 the Total Environment 344, 159-184. DOI:10.1016/j.scitotenv.2005.02.011

615 Walling, D.E., 2013. The evolution of sediment source fingerprinting investigations in fluvial systems.

616 Journal of Soils and Sediments 13, 1658-1675. DOI: 10.1007/s11368-013-0767-2

617 Zebracki, M., Eyrolle-Boyer, F., Evrard, O., Claval, D., Mourier, B., Gairoard, S., Cagnat, X.,

618 Antonelli, C., 2015. Tracing the origin of suspended sediment in a large Mediterranean river by

619 combining continuous river monitoring and measurement of artificial and natural radionuclides.

620 Science of the Total Environment 502, 122-132. DOI: 10.1016/j.scitotenv.2014.08.082 


\section{Figures}

Figure 1: Location of the Rhône River watershed in Europe and France (43.3302-4.8455). Map of the suspended particulate matter (SPM) stations of the Rhône Sediment Observatory (OSR) network (squares) and zoom on the study area of the Upper Rhône River and locations of SPM and sediment core sampling sites.

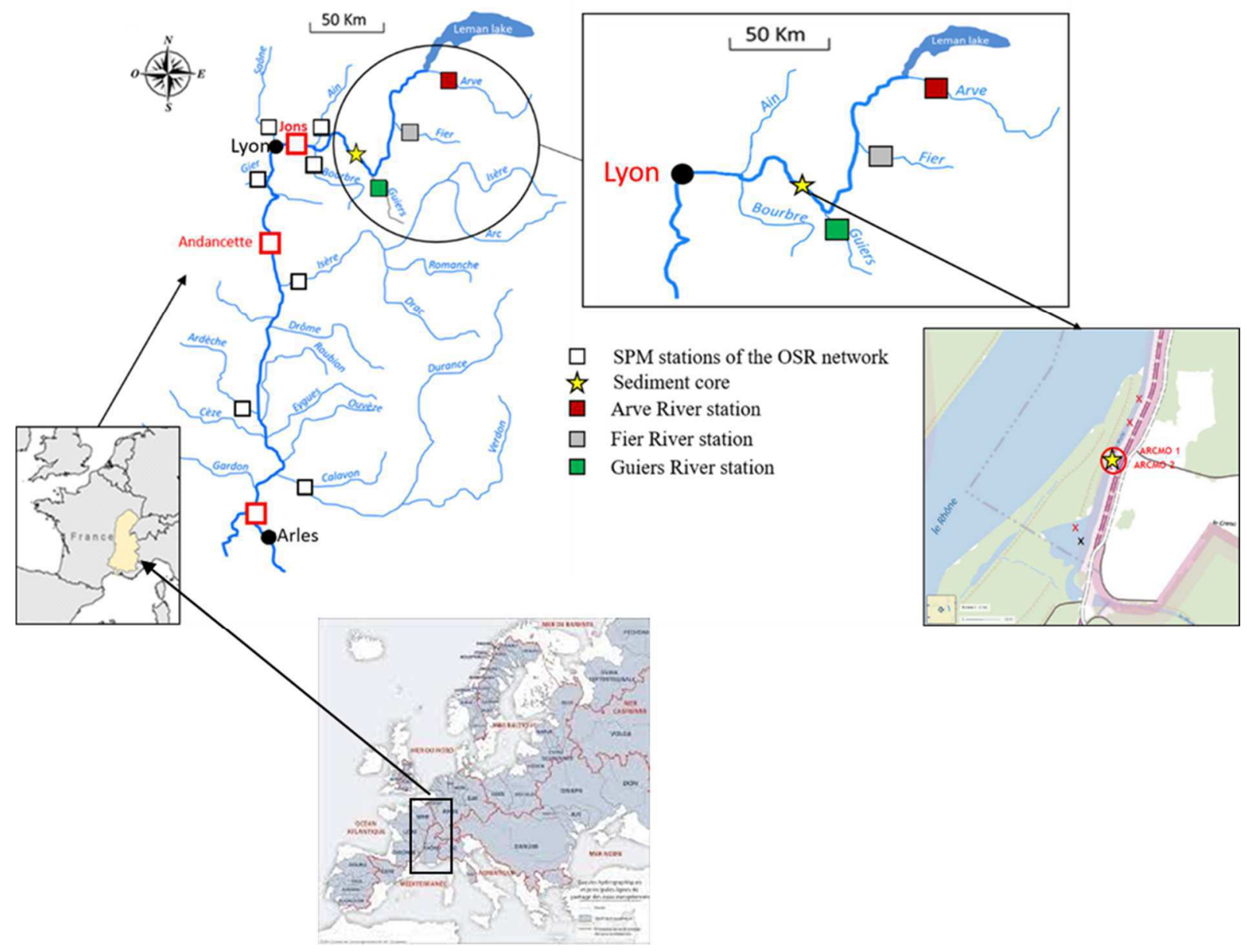


Figure 2: Metal concentrations (particle-size corrected data) in suspended particulate matter of the three tributaries of the Rhône River (Arve, Fier and Guiers Rivers) and sediment core sampled in the Rhône at La Morte site. The three identified reactivity groups represent properties that are not reactive (a), moderately reactive (b), and highly reactive (c). Concentrations in the total (blue dots) and residual (red dots) fractions.
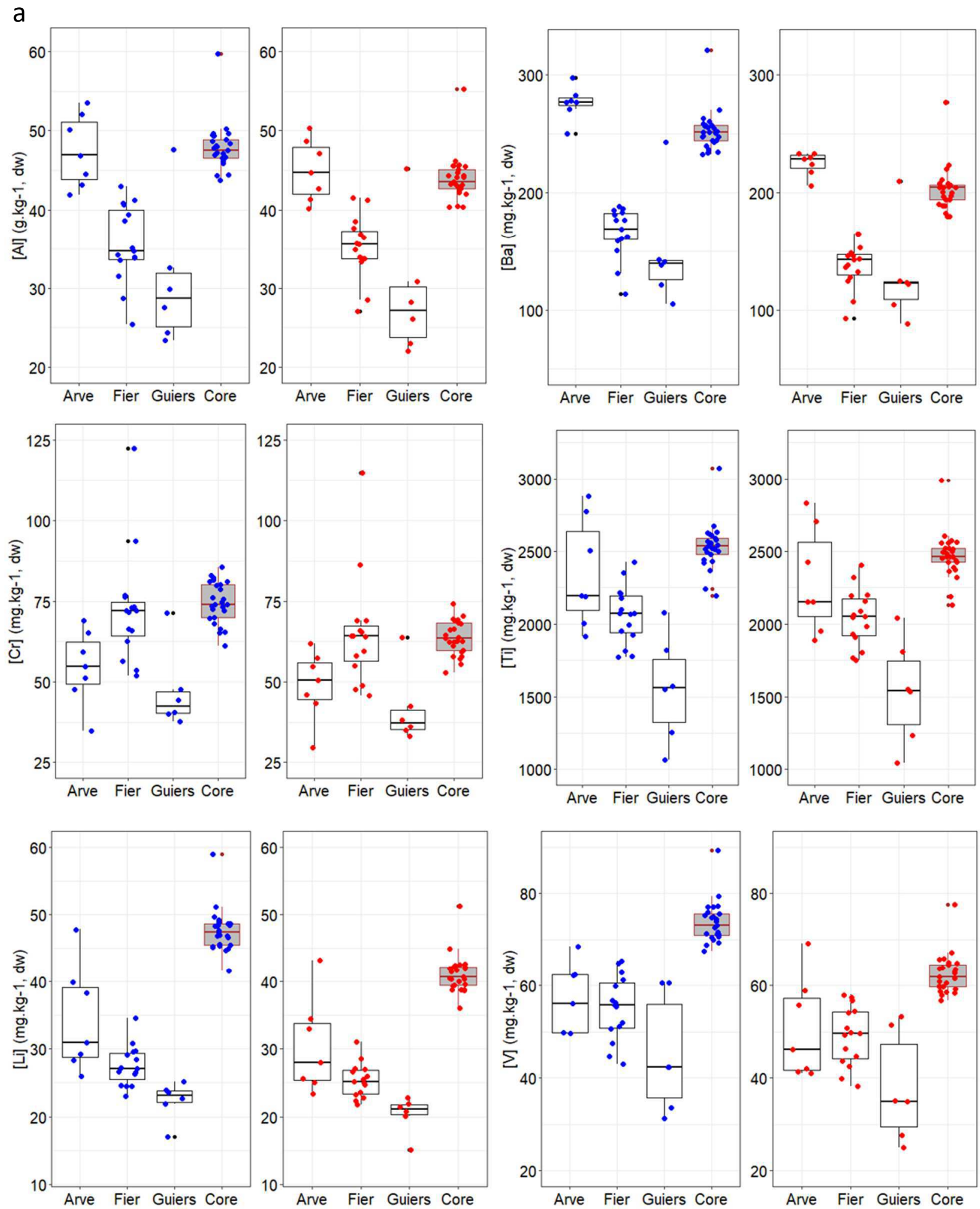
b
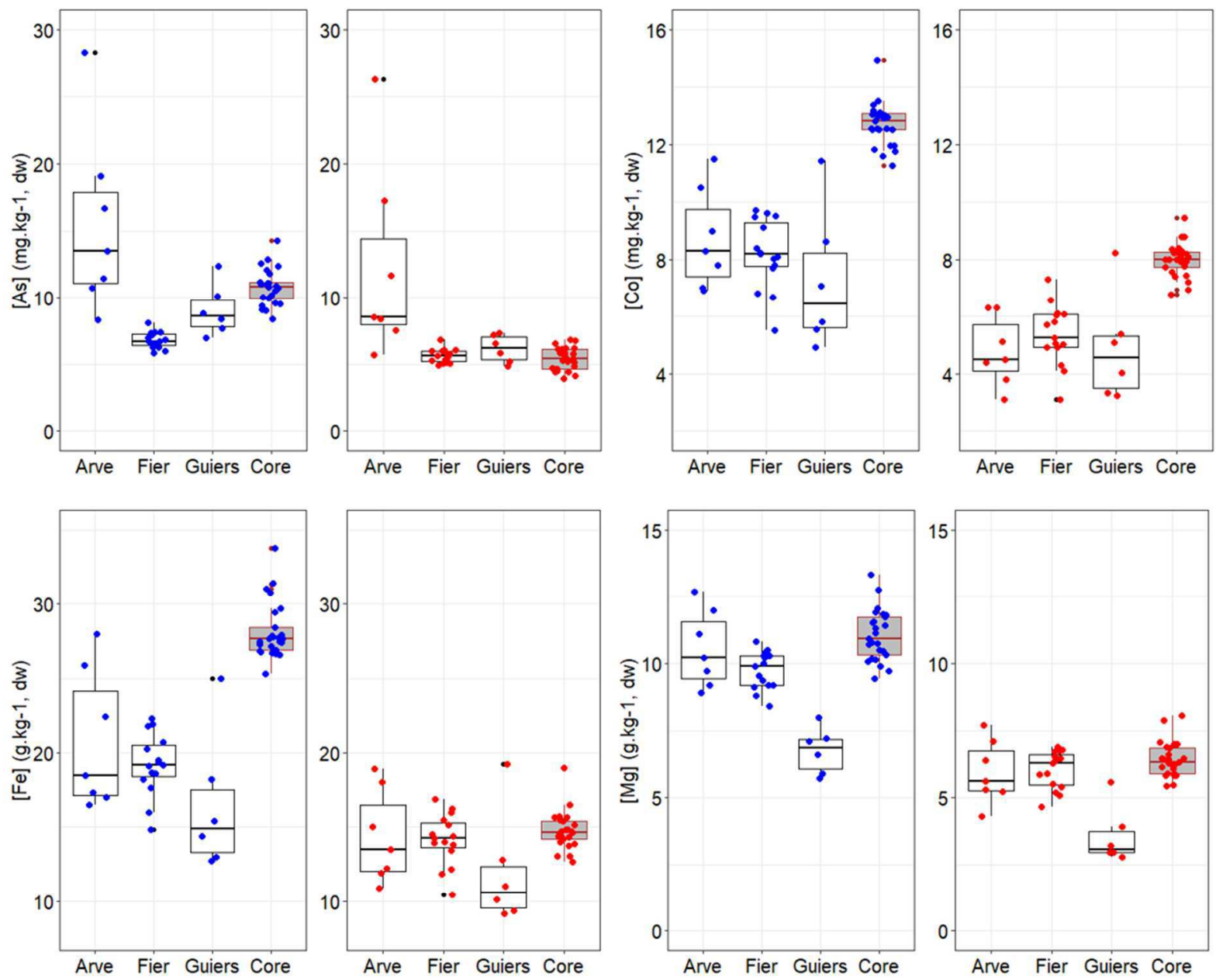
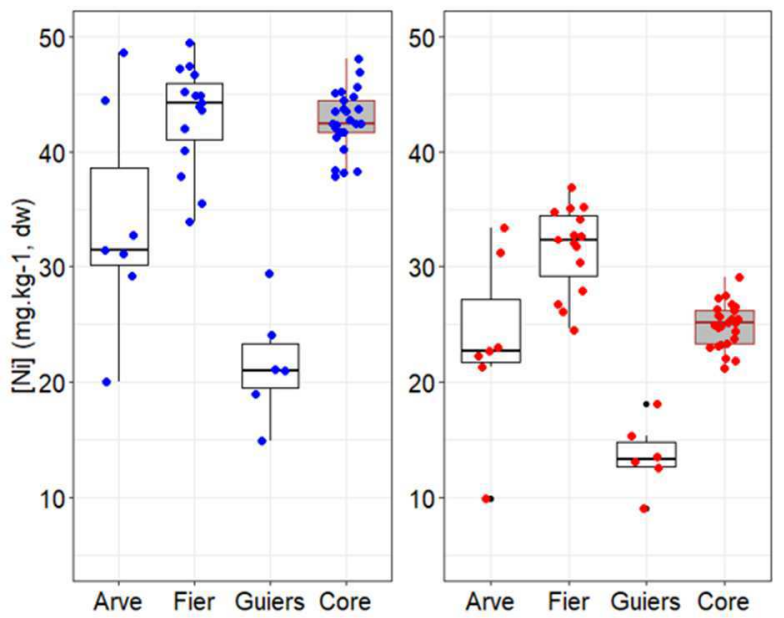
C
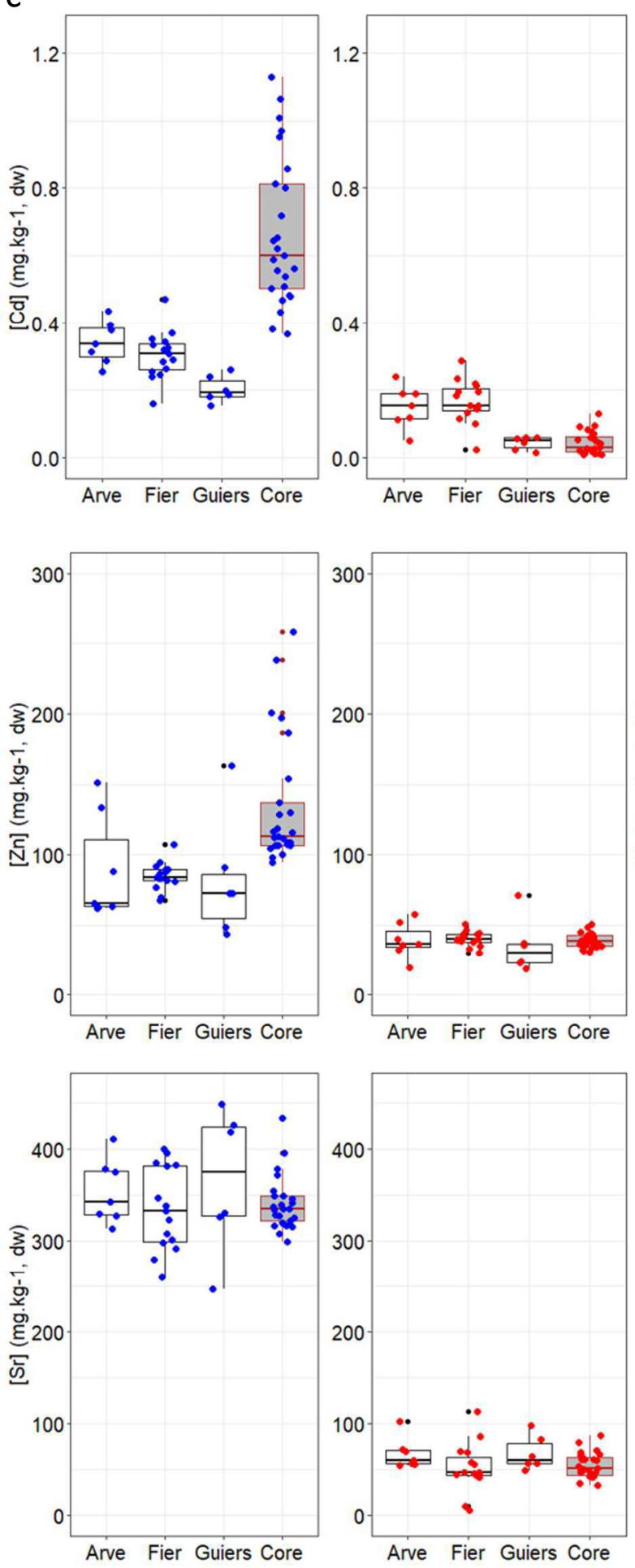
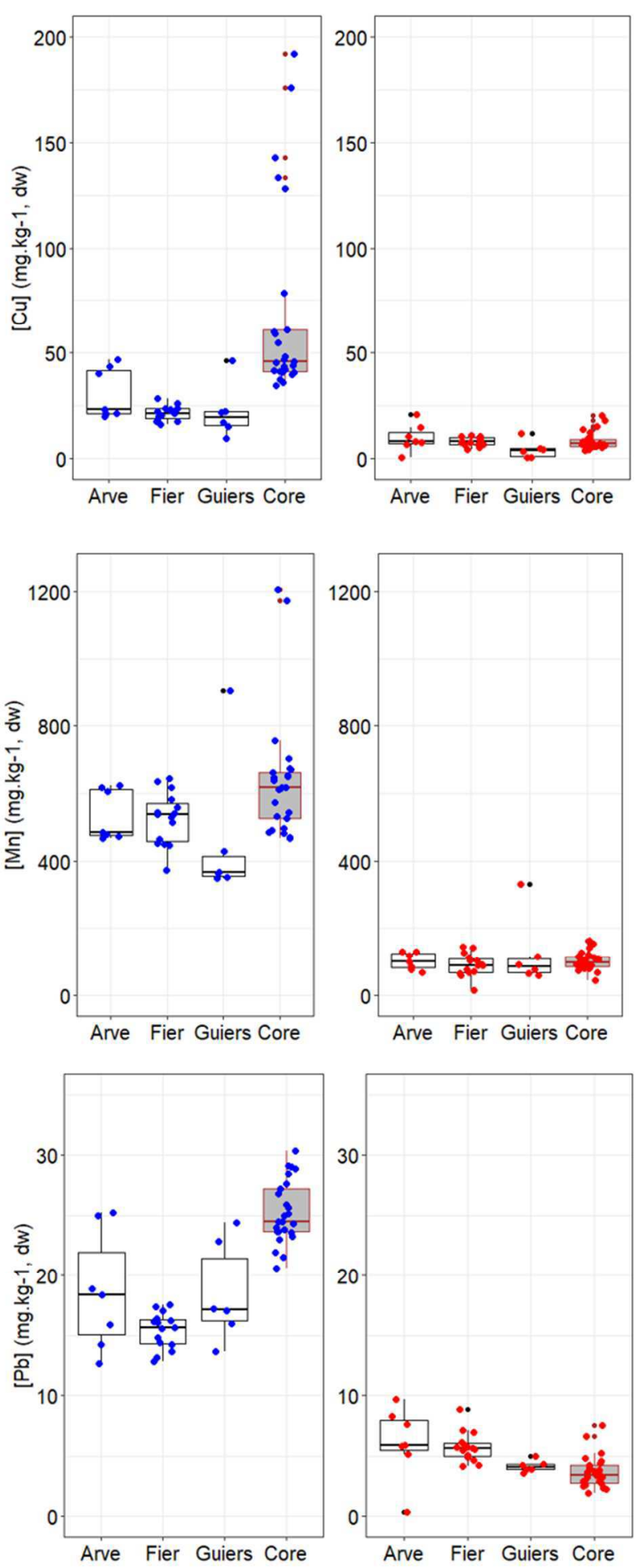
Figure 3: Metal concentrations in the sediment core sampled in the Rhône at La Morte site. The three identified reactivity groups represent properties that are not reactive (a), moderately reactive (b) and highly reactive (c). Example of three behaviours of metals along the sediment core by comparing concentrations in the total (blue line) and residual (red line) fractions.

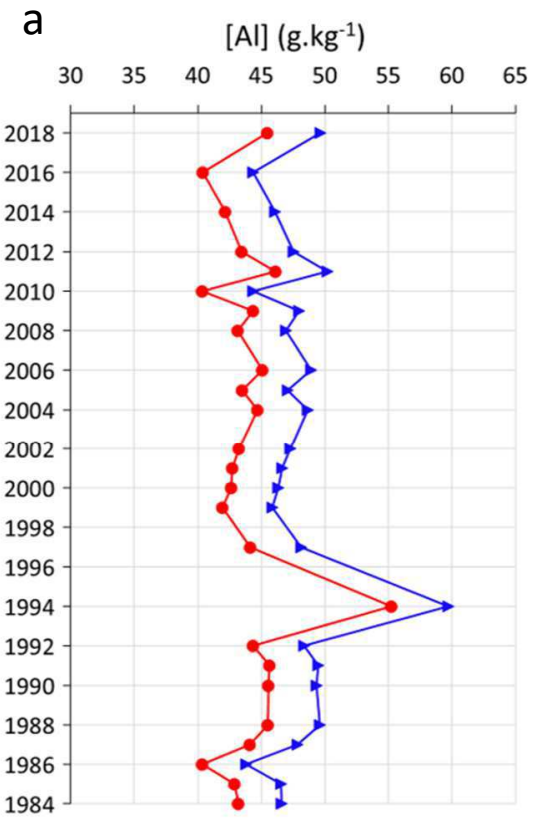

[Cr] $\left(\mathrm{mg} . \mathrm{kg}^{-1}\right)$

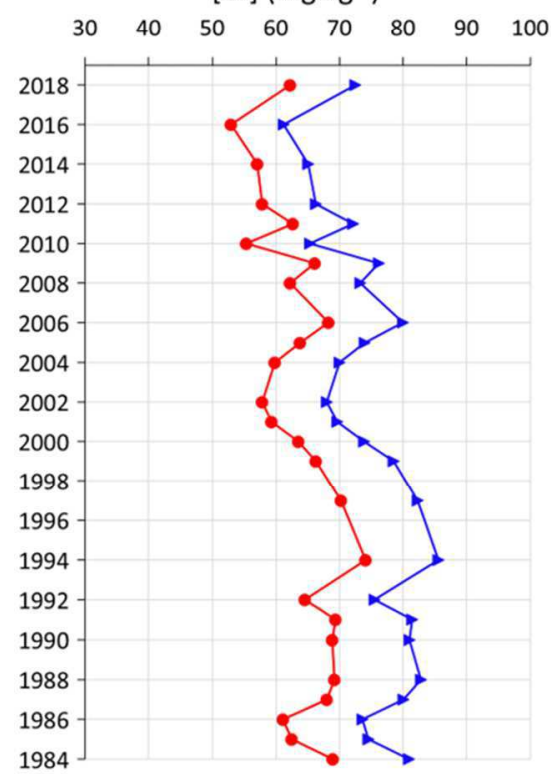

[Ti] (mg.kg-1)

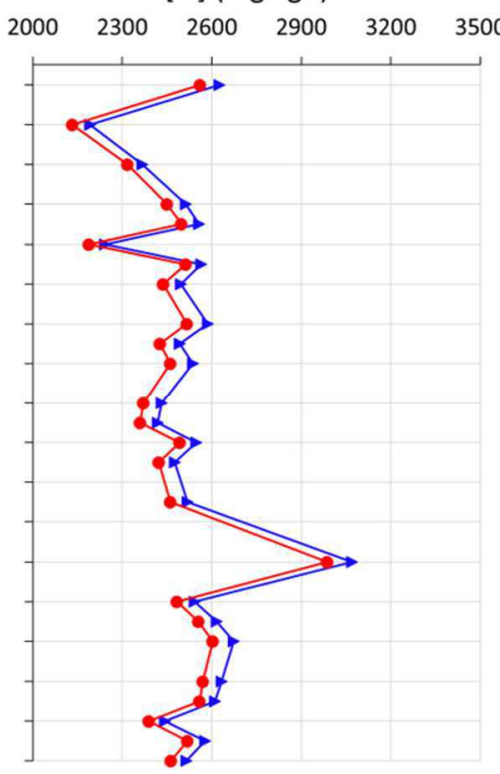

[Li] (mg.kg-1)
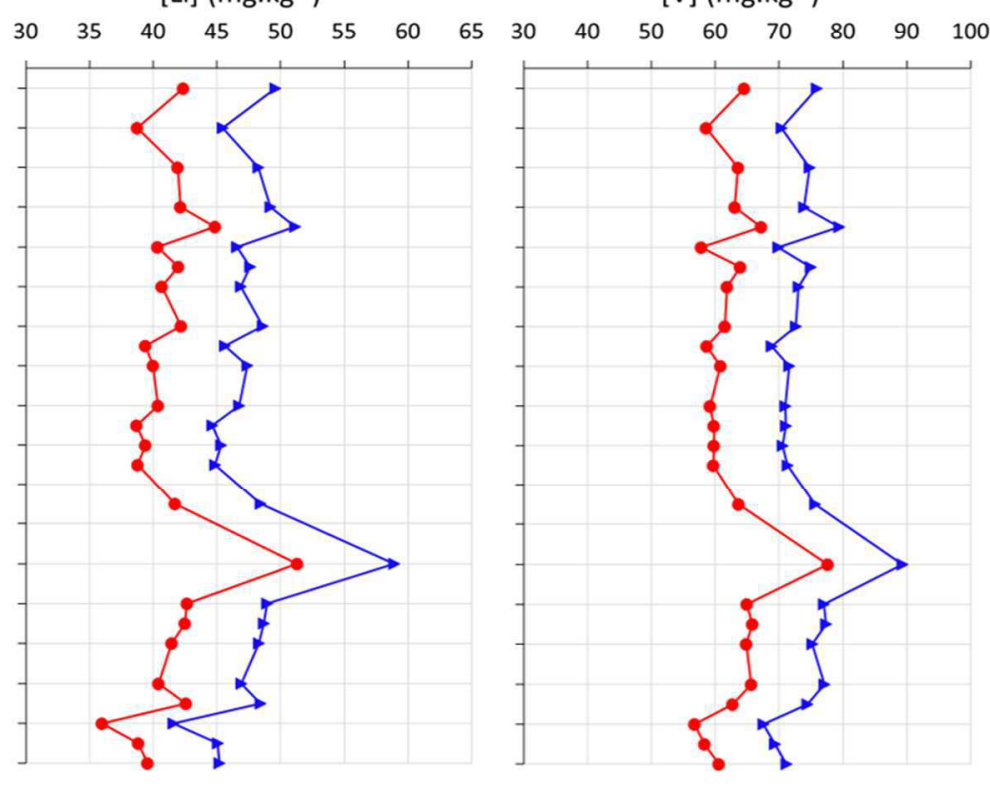

[Ba] (mg.kg ${ }^{-1}$ )

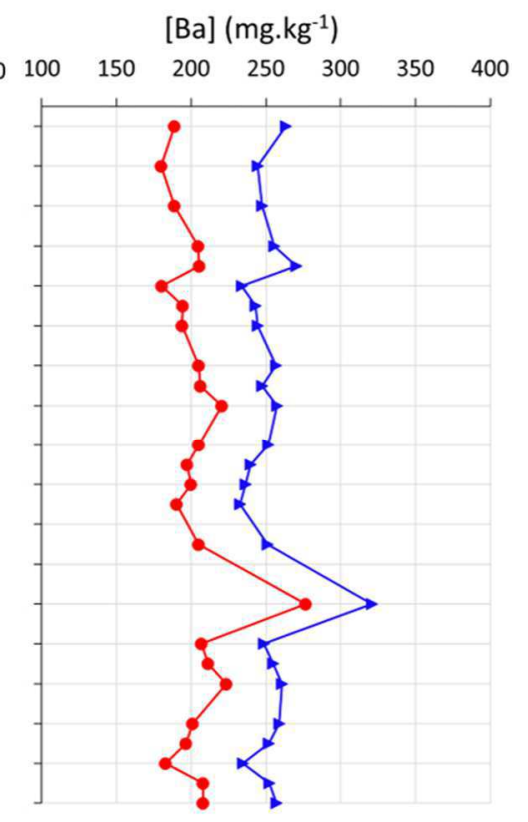

[V] (mg.kg-1)

\section{Mineralisation}

- Residual fraction

- Total fraction 
b

[As] (mg.kg $\left.\mathrm{mg}^{-1}\right) \quad[\mathrm{Co}]\left(\mathrm{mg} \cdot \mathrm{kg}^{-1}\right)$
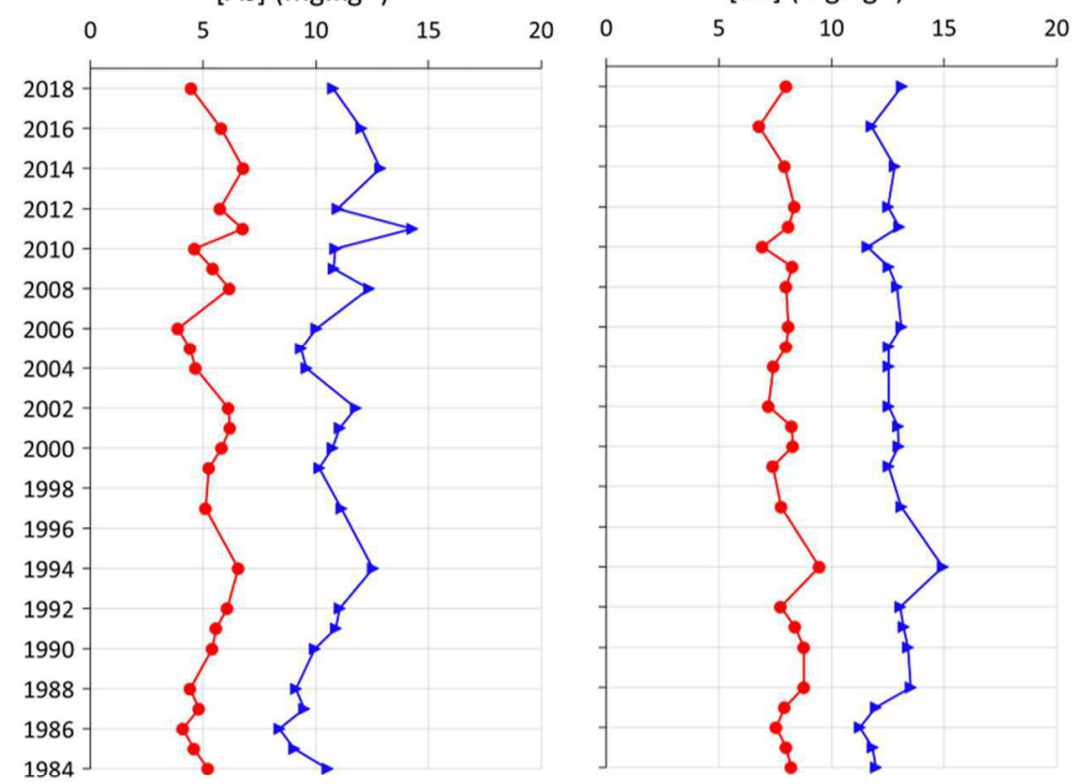

[Mg] $\left(\mathrm{g} \cdot \mathrm{kg}^{-1}\right)$

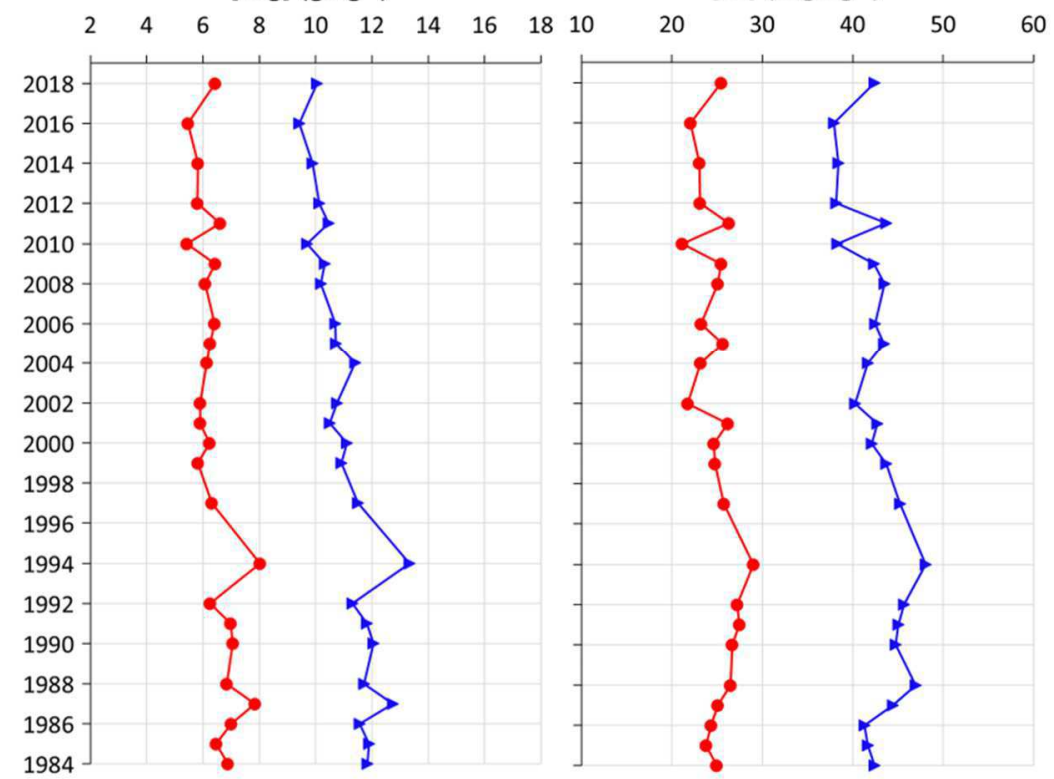

[Fe] (g.kg-1)

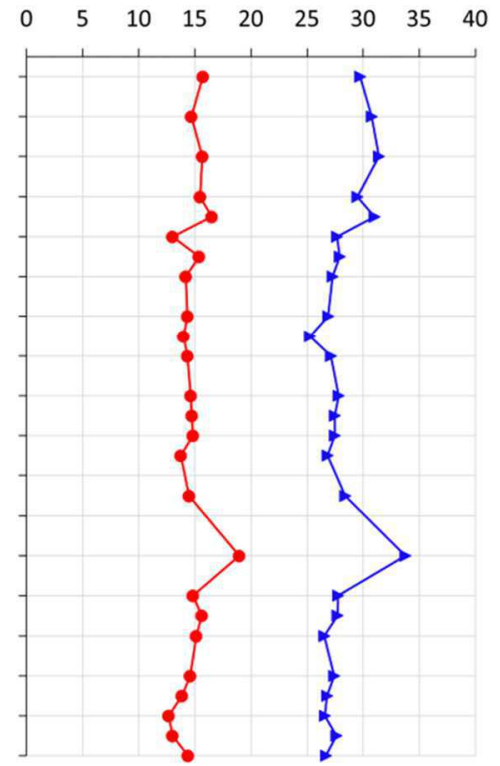

\section{Mineralisation}

- Residual fraction

- Total fraction 
C

[Cd] (mg. $\left.\mathrm{kg}^{-1}\right)$

[Cu] (mg.kg-1)

[Zn] (mg.kg $\left.{ }^{-1}\right)$
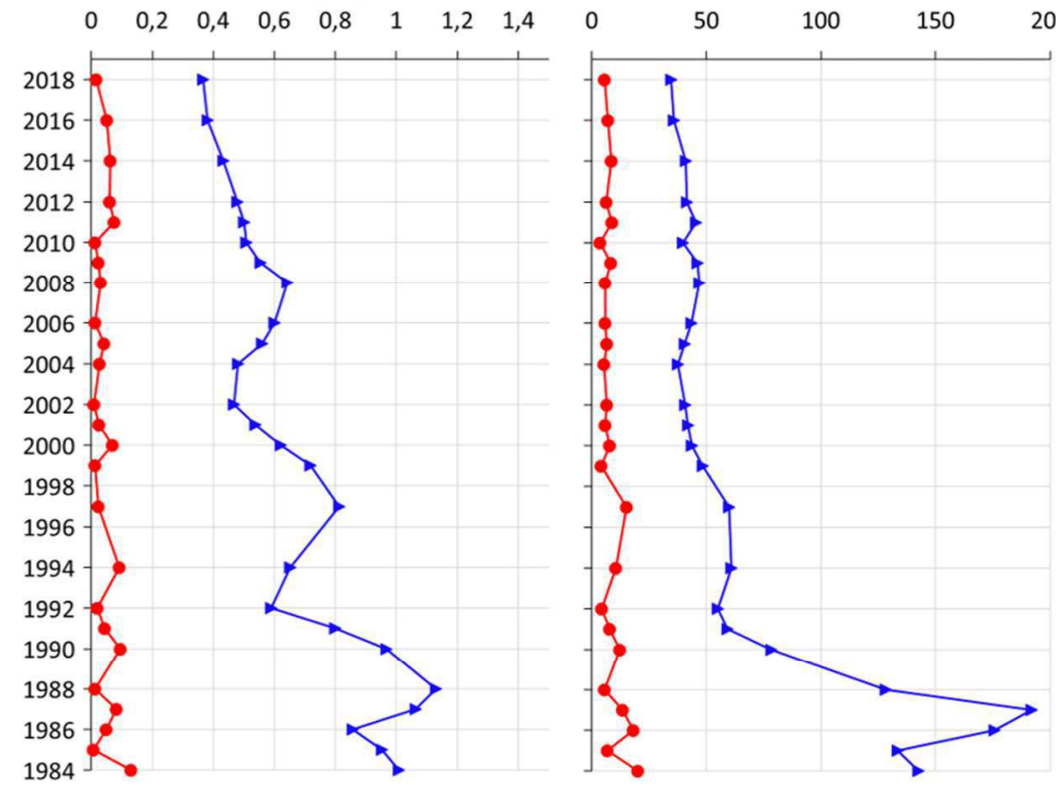

2000

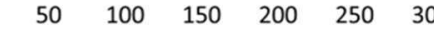

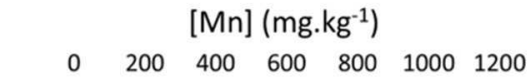
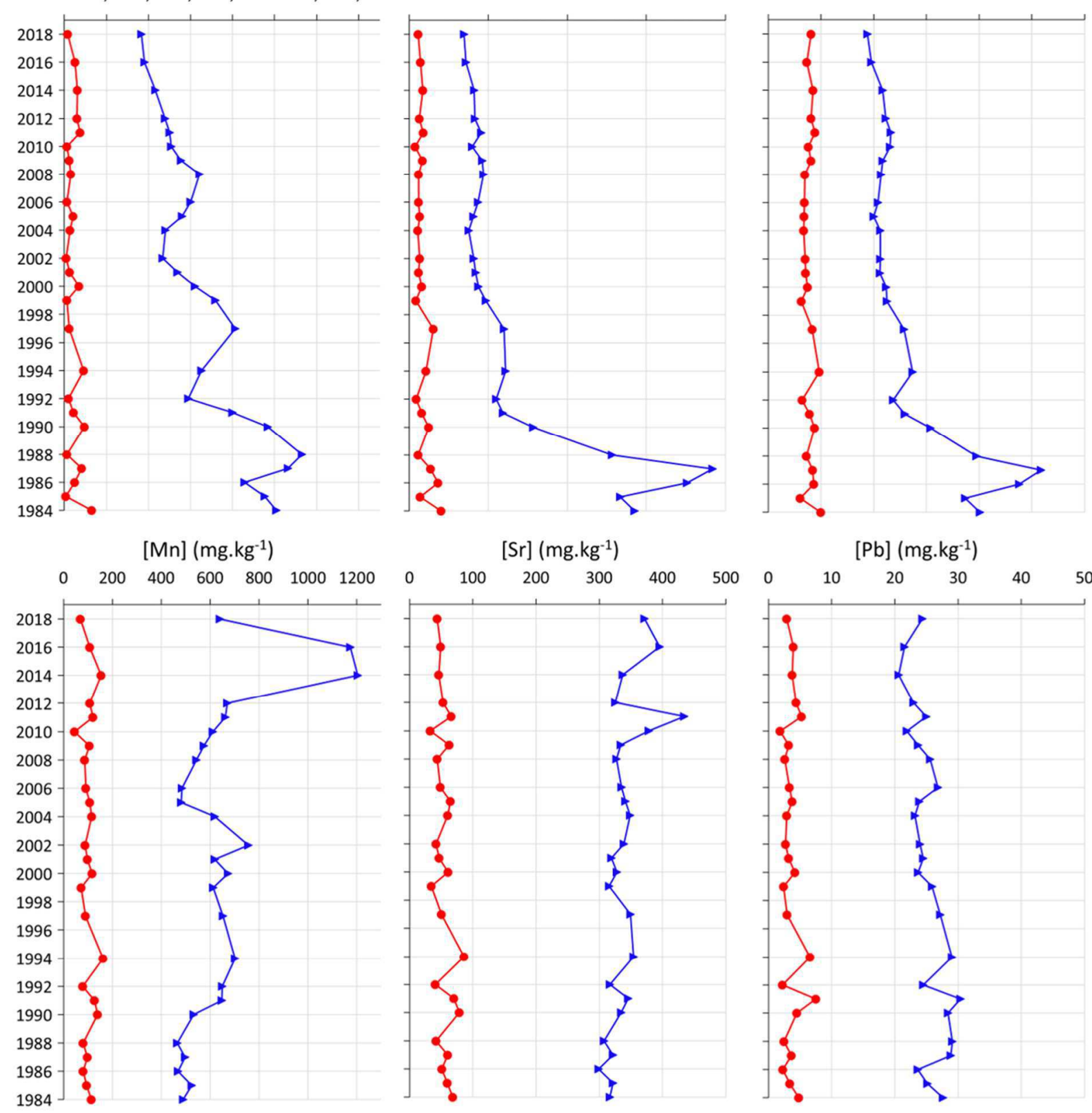

[Pb] (mg.kg-1)

Mineralisation

- Residual fraction

- Total fraction 
Figure 4: Geochemical properties excluded after the range test for the concentrations of metals in the total (a) and the residual (b) fractions of each layer of the sediment core according to the age of each sediment strata.

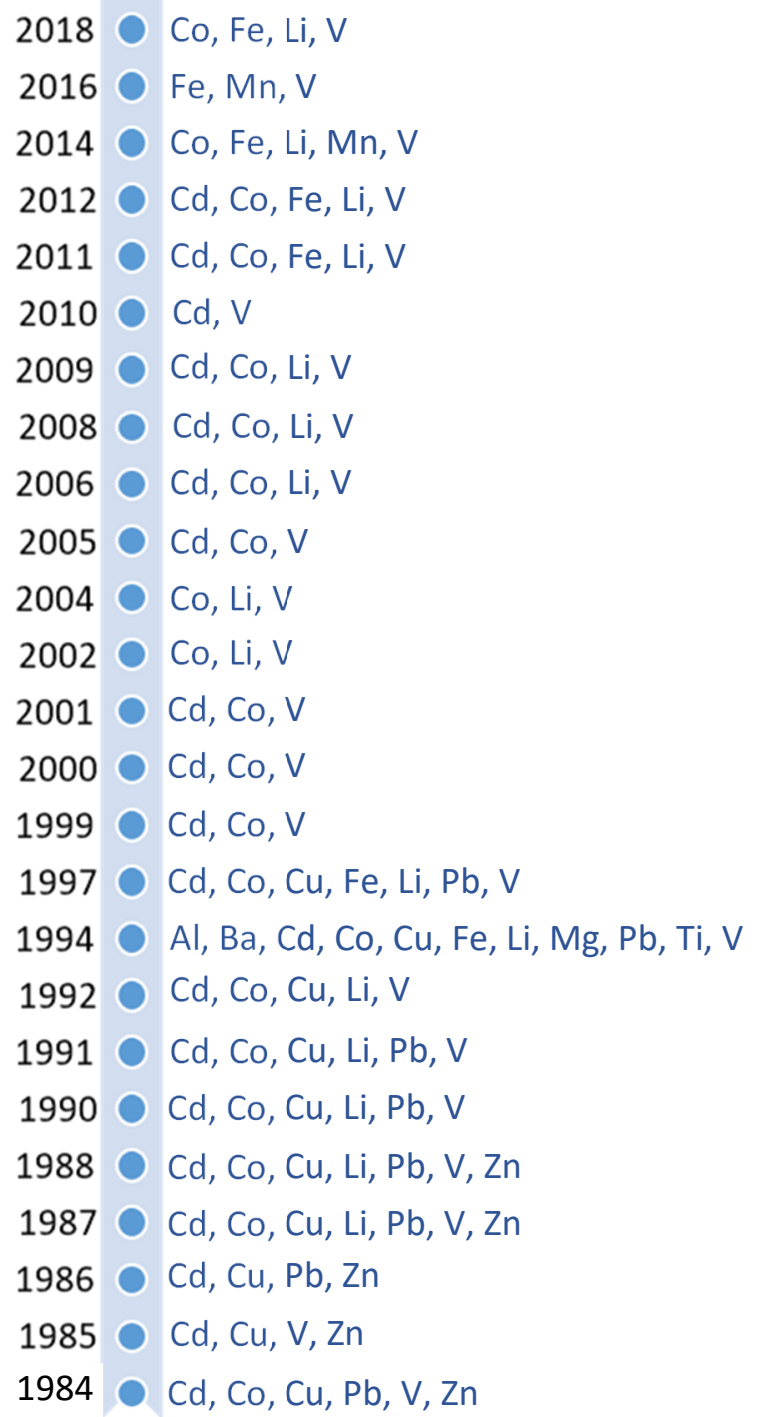

b

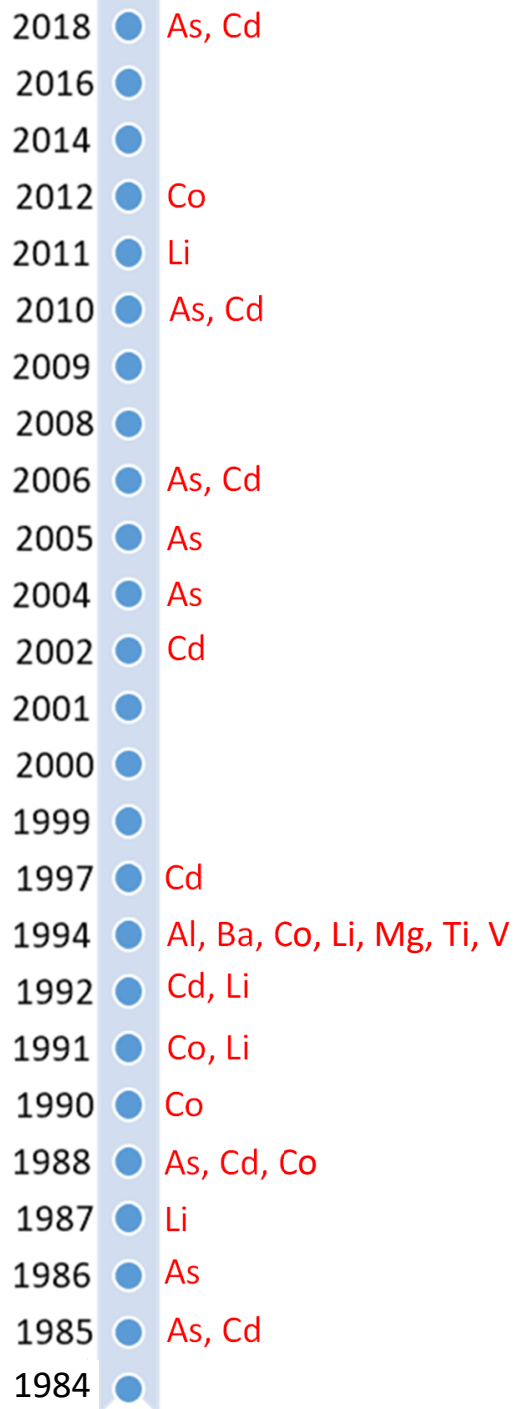


Figure 5: Historical relative SPM contributions (in \%) of the Arve, Guiers and Fier Rivers as inferred from the selected geochemical tracers in the total (a) and residual (b) fractions of the sediment core.

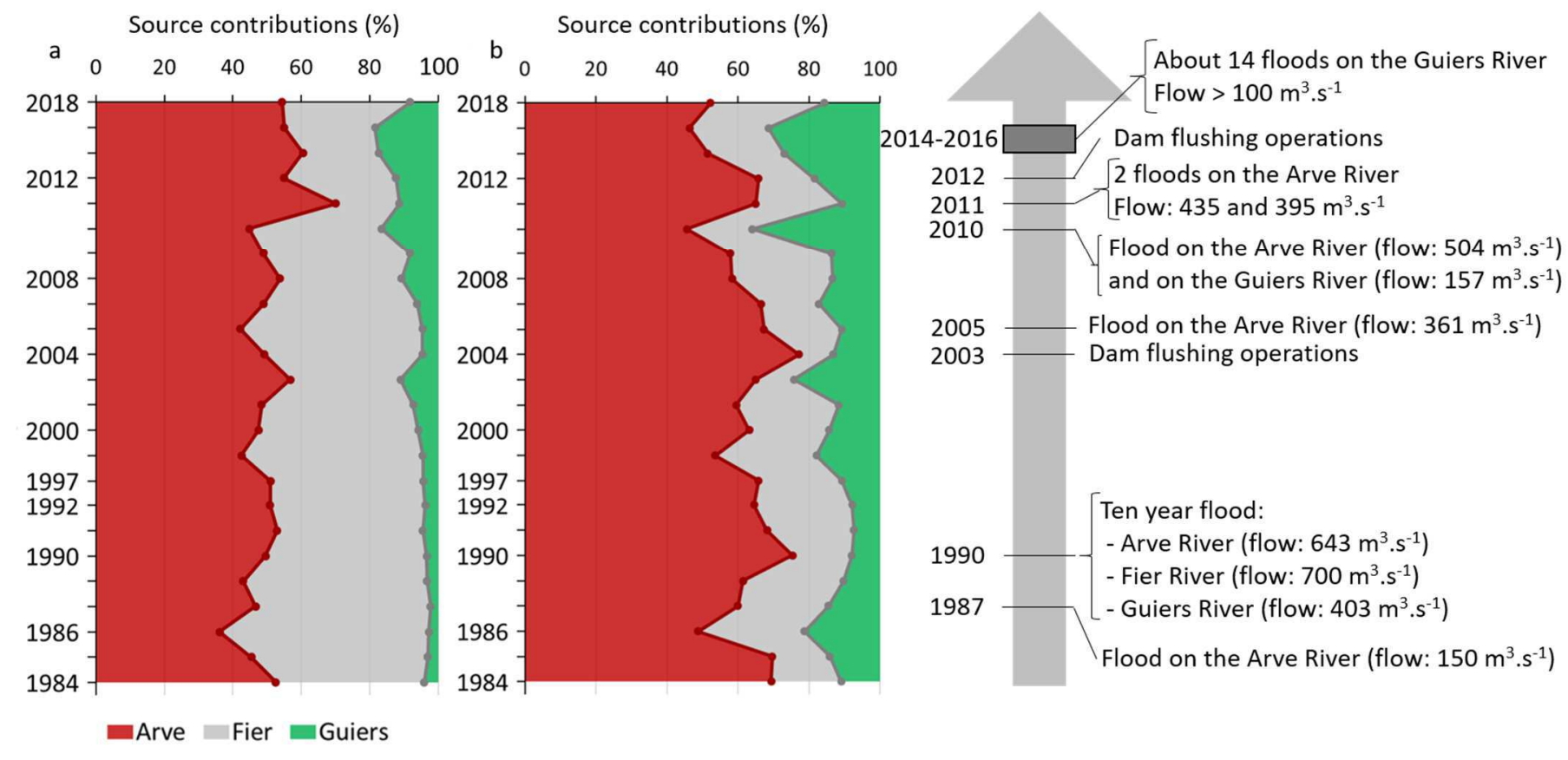


Table 1: Statistical results (Range test, Kruskal Wallis test and Discriminant Factor Analysis) for the tracer selection procedure for total and residual fractions of SPM sources. The green " $V$ " to show the geochemical tracers that are retained at each step and red " $X$ " for those that fail. For DFA, the red " $\mathrm{X}$ " shows the elements removed from the procedure while the elements retained are characterised by a value representing the discriminatory power of elements.

\begin{tabular}{|c|c|c|c|c|c|c|}
\hline \multirow{2}{*}{$\begin{array}{c}\text { Properties } \\
\text { (corrected concentrations) }\end{array}$} & \multicolumn{3}{|c|}{ Total fraction } & \multicolumn{3}{c|}{ Residual fraction } \\
\cline { 2 - 7 } & Range test & KW test & DFA & Range test & KW test & DFA \\
\hline $\mathrm{Al}$ & $\mathrm{V}$ & $\mathrm{V}$ & 100 & $\mathrm{~V}$ & $\mathrm{~V}$ & $\mathrm{X}$ \\
\hline $\mathrm{As}$ & $\mathrm{V}$ & $\mathrm{V}$ & 100 & $\mathrm{X}$ & $\mathrm{X}$ & $\mathrm{X}$ \\
\hline $\mathrm{Ba}$ & $\mathrm{V}$ & $\mathrm{V}$ & 78.6 & $\mathrm{~V}$ & $\mathrm{~V}$ & 78.6 \\
\hline $\mathrm{Cd}$ & $\mathrm{X}$ & $\mathrm{X}$ & $\mathrm{X}$ & $\mathrm{X}$ & $\mathrm{X}$ & $\mathrm{X}$ \\
\hline $\mathrm{Co}$ & $\mathrm{X}$ & $\mathrm{X}$ & $\mathrm{X}$ & $\mathrm{X}$ & $\mathrm{X}$ \\
\hline $\mathrm{Cr}$ & $\mathrm{V}$ & $\mathrm{V}$ & $\mathrm{X}$ & $\mathrm{V}$ & $\mathrm{V}$ & $\mathrm{X}$ \\
\hline $\mathrm{Cu}$ & $\mathrm{X}$ & $\mathrm{X}$ & $\mathrm{X}$ & $\mathrm{V}$ & $\mathrm{X}$ & $\mathrm{X}$ \\
\hline $\mathrm{Fe}$ & $\mathrm{X}$ & $\mathrm{X}$ & $\mathrm{X}$ & $\mathrm{V}$ & $\mathrm{X}$ & $\mathrm{X}$ \\
\hline $\mathrm{Li}$ & $\mathrm{X}$ & $\mathrm{X}$ & $\mathrm{X}$ & $\mathrm{X}$ & $\mathrm{X}$ & $\mathrm{X}$ \\
\hline $\mathrm{Mg}$ & $\mathrm{V}$ & $\mathrm{V}$ & 100 & $\mathrm{~V}$ & $\mathrm{~V}$ & $\mathrm{X}$ \\
\hline $\mathrm{Mn}$ & $\mathrm{X}$ & $\mathrm{X}$ & $\mathrm{X}$ & $\mathrm{V}$ & $\mathrm{X}$ & $\mathrm{X}$ \\
\hline $\mathrm{Ni}$ & $\mathrm{V}$ & $\mathrm{V}$ & 96.4 & $\mathrm{~V}$ & $\mathrm{~V}$ & 96.4 \\
\hline $\mathrm{Pb}$ & $\mathrm{X}$ & $\mathrm{X}$ & $\mathrm{X}$ & $\mathrm{V}$ & $\mathrm{V}$ & $\mathrm{X}$ \\
\hline $\mathrm{Sr}$ & $\mathrm{V}$ & $\mathrm{X}$ & $\mathrm{X}$ & $\mathrm{V}$ & $\mathrm{X}$ & $\mathrm{X}$ \\
\hline $\mathrm{Ti}$ & $\mathrm{V}$ & $\mathrm{V}$ & $\mathrm{X}$ & $\mathrm{V}$ & $\mathrm{V}$ & $\mathrm{X}$ \\
\hline $\mathrm{V}$ & $\mathrm{X}$ & $\mathrm{X}$ & $\mathrm{X}$ & $\mathrm{V}$ & $\mathrm{X}$ & $\mathrm{X}$ \\
\hline $\mathrm{Zn}$ & $\mathrm{X}$ & $\mathrm{X}$ & $\mathrm{X}$ & $\mathrm{V}$ & $\mathrm{X}$ & $\mathrm{X}$ \\
\hline
\end{tabular}




\section{Supplementary Material 1: Analytical procedures for suspended particulate matter (SPM) and sediment samples}

Particle size distribution was analyzed on fresh SPM samples using a Cilas 1190 particle size analyzer, according to ISO standard 13320 (ISO, 2009) under ultrasound and sample agitation. For the sediment core samples, grain size analysis was performed on a Mastersizer $2000^{\odot}$ (Malvern Panalytical, Instruments Ltd., Malvern, UK) with a hydro SM small volume wet dispersion unit.

The analysis of geochemical properties involved the quantification of 20 trace and major elements in two fractions: total fraction and reactive fraction. The total fraction was determined after triacid mineralization (nitric acid, hydrochloric acid and hydrofluoric acid, proportioned $1.5 \mathrm{~mL} \mathrm{HCl} \mathrm{12M,}$ $0.5 \mathrm{~mL} \mathrm{HNO}_{3} 14 \mathrm{M}, 2 \mathrm{~mL} \mathrm{HF} 22 \mathrm{M}$ on a heating plate. The reactive fraction was obtained by a soft extraction using hydrochloric acid (1 M) at room temperature (Dabrin et al., 2014). Metals were analyzed in both fractions by inductively-coupled plasma optical emission spectroscopy (ICP-OES, Agilent 720-ES, Agilent Technologies) or triple quadrupole inductively-coupled plasma mass spectrometry (TQ-ICP-MS, Thermo iCAP-TQ, Thermo Fisher Scientific) according to their limit of quantification (Table S1) and the concentration in the samples. Aluminium (Al), barium (Ba), cobalt (Co), chromium $(\mathrm{Cr})$, copper $(\mathrm{Cu})$, iron $(\mathrm{Fe})$, magnesium $(\mathrm{Mg})$, manganese $(\mathrm{Mn})$, strontium $(\mathrm{Sr})$, titanium (Ti), vanadium (V) and zinc (Zn) were analyzed by ICP-OES. Arsenic (As), cadmium (Cd), lithium $(\mathrm{Li})$, nickel $(\mathrm{Ni})$ and lead $(\mathrm{Pb})$ concentrations were determined by TQ-ICP-MS. To control the accuracy of the results, certified reference materials (IAEA-158, marine sediment for total extraction, and LGC-6187, river sediment) were analyzed in triplicate for each analytical series. Coefficient of variation was lower than $11 \%$ for each element analyzed (Table S2). In addition, blanks were systematically included in mineralization and analytical series to confirm that the samples were not contaminated during the analytical process.

A Student's $t$-test or Wilcoxon test was used to compare tracer concentrations between total and nonreactive fractions of SPM, concentrations of metals between tributaries, and concentrations of metals between the top and the bottom of the sediment core. Level of significance was 0.05 . 
Table S1: Limits of quantification of trace (expressed in $\mathrm{mg} \mathrm{kg}^{-1}$ ) and major (expressed in $\mathrm{g} \mathrm{kg}^{-1}$ ) metals according to the analytical technique used in this study (ICP-OES and ICP-MS).

\begin{tabular}{|c|c|c|c|c|c|c|}
\hline \multirow{3}{*}{ Metals } & \multicolumn{4}{|c|}{ ICP-OES } & \multicolumn{2}{|c|}{ ICP-MS } \\
\hline & \multicolumn{2}{|c|}{ LQ_total extraction } & \multicolumn{2}{|c|}{ LQ_HCl extraction } & \multirow{2}{*}{$\begin{array}{c}\text { LQ_total extraction } \\
\mathrm{mg} \mathrm{kg}^{-1}\end{array}$} & \multirow{2}{*}{$\begin{array}{c}\text { LQ_HCl } \\
\text { extraction } \\
\mathrm{mg} \mathrm{kg}^{-1}\end{array}$} \\
\hline & $\mathrm{g} \mathrm{kg}^{-1}$ & $\mathrm{mg} \mathrm{kg}^{-1}$ & $\mathrm{~g} \mathrm{~kg}^{-1}$ & $\mathrm{mg} \mathrm{kg}_{1}^{-}$ & & \\
\hline $\mathrm{Ag}$ & & & & & 0.025 & 0.0063 \\
\hline $\mathrm{Al}$ & 2.5 & & 0.63 & & & \\
\hline As & & & & & 0.025 & 0.0063 \\
\hline $\mathrm{Ba}$ & & 2.5 & & 0.63 & & \\
\hline $\mathrm{Cd}$ & & & & & 0.025 & 0.0063 \\
\hline Co & & 2.5 & & 0.63 & & \\
\hline $\mathrm{Cr}$ & & 5.0 & & 1.25 & & \\
\hline $\mathrm{Cu}$ & & 5.0 & & 0.63 & & \\
\hline $\mathrm{Fe}$ & 2.5 & & 0.63 & & & \\
\hline $\mathrm{Li}$ & & & & & 0.025 & 0.0063 \\
\hline $\mathrm{Mg}$ & 2.5 & & 0.63 & & & \\
\hline $\mathrm{Mn}$ & & 2.5 & & 0.63 & & \\
\hline $\mathrm{Ni}$ & & & & & 0.05 & 0.0125 \\
\hline $\mathrm{Pb}$ & & & & & 0.025 & 0.0125 \\
\hline $\mathrm{Sr}$ & & 2.5 & & 0.63 & & \\
\hline $\mathrm{Ti}$ & & 2.5 & & 0.63 & & \\
\hline V & & 2.5 & & 0.63 & & \\
\hline $\mathrm{Zn}$ & & 2.5 & & 0.63 & & \\
\hline
\end{tabular}


Table S2: Coefficient of variation (\%) associated with metals and analytical techniques (ICP-OES and TQ-ICP-MS).

\begin{tabular}{|c|c|c|c|c|}
\hline \multirow[t]{2}{*}{ Metals } & \multicolumn{2}{|c|}{$\begin{array}{l}\text { Coefficient of variation } \\
\text { ICP-OES (\%) }\end{array}$} & \multicolumn{2}{|c|}{$\begin{array}{c}\text { Coefficient of variation } \\
\text { TQ-ICP-MS (\%) }\end{array}$} \\
\hline & Total extraction & $\mathrm{HCl}$ extraction & Total extraction & $\mathrm{HCl}$ extraction \\
\hline $\mathrm{Al}$ & 8.3 & 8.9 & - & - \\
\hline As & - & & 9.3 & 4.2 \\
\hline $\mathrm{Ba}$ & 7.7 & 4.1 & - & - \\
\hline $\mathrm{Cd}$ & - & & 9.3 & 7.9 \\
\hline Co & 8.2 & 7.9 & - & - \\
\hline $\mathrm{Cr}$ & 9.4 & 10.0 & - & - \\
\hline $\mathrm{Cu}$ & 9.1 & 10.9 & - & - \\
\hline $\mathrm{Fe}$ & 7.0 & 8.8 & - & - \\
\hline $\mathrm{Li}$ & - & - & 6.3 & 9.5 \\
\hline $\mathrm{Mg}$ & 8.1 & 6.7 & - & - \\
\hline $\mathrm{Mn}$ & 9.4 & 5.4 & - & - \\
\hline $\mathrm{Ni}$ & - & - & 7.3 & 4.9 \\
\hline $\mathrm{Pb}$ & - & - & 4.5 & 5.1 \\
\hline $\mathrm{Sr}$ & 5.4 & 4.0 & - & - \\
\hline $\mathrm{Ti}$ & 9.0 & 8.6 & - & - \\
\hline V & 6.6 & 5.8 & - & - \\
\hline $\mathrm{Zn}$ & 9.2 & 8.0 & - & - \\
\hline
\end{tabular}

The sediment core was dated using ${ }^{210} \mathrm{~Pb}$ xs $\left({ }^{210} \mathrm{~Pb}\right.$ in excess $)$ and ${ }^{137} \mathrm{Cs}$ concentrations, which are widely used to date contemporaneous ( $<100$ years) sediment cores (Appleby, 1998). Dry samples of sediment were conditioned in 17 or $60 \mathrm{~mL}$ boxing depending on the quantity of sediment available. Each box was placed in vacuum-sealed packages and stored for at least one month before measurement with a germanium detector to ensure the secular equilibrium of the ${ }^{210} \mathrm{~Pb}$ necessary to determine the concentration of ${ }^{210} \mathrm{~Pb}_{\mathrm{xs}}$ (Morereau et al., 2020).

A peak of ${ }^{137} \mathrm{Cs}$, related to the atmospheric fallout from Chernobyl in 1986, was observed at a depth of $90 \mathrm{~cm}$ and used as a proxy to date the sediment core. According to ${ }^{210} \mathrm{~Pb}_{\mathrm{xs}}$, sedimentation rate was estimated to be $2.9 \mathrm{~cm}$ year-1 factoring in the $31 \%$ compaction. Dating was confirmed using additional information input such as flood events (Morereau et al., 2020). 
Supplementary Material 2: Results of statistical tests ( $t$ test or Wilcoxon test) comparing the concentrations of metals (1) for each tributary (Arve, Fier and Guiers Rivers) and for the sediment core between both analytical fractions and (2) between each tributary and the sediment core for both fractions.

Table SI.1: The green "V" show the significant differences between the concentrations of metal measured in the total and residual fractions $(p<0.05)$ and the red " $X$ " for those that show no significant differences.

\begin{tabular}{|c|c|c|c|c|}
\hline Metals & Arve River & Fier River & Guiers River & Sediment core \\
\hline $\mathrm{Al}$ & $\mathrm{X}$ & $\mathrm{X}$ & $\mathrm{X}$ & $\mathrm{V}$ \\
\hline $\mathrm{As}$ & $\mathrm{X}$ & $\mathrm{V}$ & $\mathrm{V}$ & $\mathrm{V}$ \\
\hline $\mathrm{Ba}$ & $\mathrm{V}$ & $\mathrm{V}$ & $\mathrm{X}$ & $\mathrm{V}$ \\
\hline $\mathrm{Cd}$ & $\mathrm{V}$ & $\mathrm{V}$ & $\mathrm{V}$ & $\mathrm{V}$ \\
\hline $\mathrm{Co}$ & $\mathrm{V}$ & $\mathrm{V}$ & $\mathrm{X}$ & $\mathrm{V}$ \\
\hline $\mathrm{Cr}$ & $\mathrm{X}$ & $\mathrm{X}$ & $\mathrm{X}$ & $\mathrm{V}$ \\
\hline $\mathrm{Cu}$ & $\mathrm{V}$ & $\mathrm{V}$ & $\mathrm{V}$ & $\mathrm{V}$ \\
\hline $\mathrm{Fe}$ & $\mathrm{V}$ & $\mathrm{V}$ & $\mathrm{X}$ & $\mathrm{V}$ \\
\hline $\mathrm{Li}$ & $\mathrm{X}$ & $\mathrm{V}$ & $\mathrm{X}$ & $\mathrm{V}$ \\
\hline $\mathrm{Mg}$ & $\mathrm{V}$ & $\mathrm{V}$ & $\mathrm{V}$ & $\mathrm{V}$ \\
\hline $\mathrm{Mn}$ & $\mathrm{V}$ & $\mathrm{V}$ & $\mathrm{V}$ & $\mathrm{V}$ \\
\hline $\mathrm{Ni}$ & $\mathrm{V}$ & $\mathrm{V}$ & $\mathrm{V}$ & $\mathrm{V}$ \\
\hline $\mathrm{Pb}$ & $\mathrm{V}$ & $\mathrm{V}$ & $\mathrm{V}$ & $\mathrm{V}$ \\
\hline $\mathrm{Sr}$ & $\mathrm{V}$ & $\mathrm{V}$ & $\mathrm{V}$ & $\mathrm{V}$ \\
\hline $\mathrm{Ti}$ & $\mathrm{X}$ & $\mathrm{X}$ & $\mathrm{X}$ & $\mathrm{V}$ \\
\hline $\mathrm{V}$ & $\mathrm{X}$ & $\mathrm{V}$ & $\mathrm{X}$ & $\mathrm{V}$ \\
\hline $\mathrm{Zn}$ & $\mathrm{V}$ & $\mathrm{V}$ & $\mathrm{V}$ & $\mathrm{V}$ \\
\hline
\end{tabular}


Table SI.2: Results of statistical tests ( $t$ test or Wilcoxon test) comparing D50 and concentrations (particle size corrected) of properties in the three sources (Arve, Fier and Guiers Rivers) and the sediment core. The green " $\mathrm{V}$ " to show the significant differences between samples $(\mathrm{p}<0.05)$ and red " $\mathrm{X}$ " for those that show no significant differences.

\begin{tabular}{|c|c|c|c|c|c|c|}
\hline \multirow{2}{*}{ Properties } & \multicolumn{3}{|c|}{ Total fraction } & \multicolumn{3}{c|}{ Residual fraction } \\
\cline { 2 - 7 } & Arve vs Core & Fier vs Core & Guiers vs Core & Arve vs Core & Fier vs Core & Guiers vs Core \\
\hline D50 & $\mathrm{X}$ & $\mathrm{V}$ & $\mathrm{X}$ & $\mathrm{X}$ & $\mathrm{V}$ & $\mathrm{X}$ \\
\hline $\mathrm{Al}$ & $\mathrm{X}$ & $\mathrm{V}$ & $\mathrm{V}$ & $\mathrm{X}$ & $\mathrm{V}$ & $\mathrm{V}$ \\
\hline $\mathrm{As}$ & $\mathrm{X}$ & $\mathrm{V}$ & $\mathrm{V}$ & $\mathrm{V}$ & $\mathrm{X}$ & $\mathrm{X}$ \\
\hline $\mathrm{Ba}$ & $\mathrm{V}$ & $\mathrm{V}$ & $\mathrm{V}$ & $\mathrm{V}$ & $\mathrm{V}$ & $\mathrm{V}$ \\
\hline $\mathrm{Cd}$ & $\mathrm{V}$ & $\mathrm{V}$ & $\mathrm{V}$ & $\mathrm{V}$ & $\mathrm{V}$ & $\mathrm{V}$ \\
\hline $\mathrm{Co}$ & $\mathrm{V}$ & $\mathrm{V}$ & $\mathrm{V}$ & $\mathrm{V}$ & $\mathrm{X}$ & $\mathrm{V}$ \\
\hline $\mathrm{Cr}$ & $\mathrm{V}$ & $\mathrm{X}$ & $\mathrm{V}$ & $\mathrm{V}$ & $\mathrm{X}$ & $\mathrm{V}$ \\
\hline $\mathrm{Cu}$ & $\mathrm{V}$ & $\mathrm{V}$ & $\mathrm{V}$ & $\mathrm{X}$ & $\mathrm{X}$ & $\mathrm{V}$ \\
\hline $\mathrm{Fe}$ & $\mathrm{V}$ & $\mathrm{V}$ & $\mathrm{V}$ & $\mathrm{X}$ & $\mathrm{V}$ & $\mathrm{V}$ \\
\hline $\mathrm{Li}$ & $\mathrm{V}$ & $\mathrm{V}$ & $\mathrm{V}$ & $\mathrm{V}$ & $\mathrm{X}$ & $\mathrm{V}$ \\
\hline $\mathrm{Mg}$ & $\mathrm{X}$ & $\mathrm{V}$ & $\mathrm{V}$ & $\mathrm{V}$ & $\mathrm{X}$ & $\mathrm{X}$ \\
\hline $\mathrm{Mn}$ & $\mathrm{X}$ & $\mathrm{V}$ & $\mathrm{V}$ & $\mathrm{X}$ & $\mathrm{V}$ & $\mathrm{V}$ \\
\hline $\mathrm{Ni}$ & $\mathrm{X}$ & $\mathrm{X}$ & $\mathrm{V}$ & $\mathrm{X}$ & $\mathrm{V}$ & $\mathrm{X}$ \\
\hline $\mathrm{Pb}$ & $\mathrm{V}$ & $\mathrm{V}$ & $\mathrm{V}$ & $\mathrm{V}$ & $\mathrm{V}$ & $\mathrm{X}$ \\
\hline $\mathrm{Sr}$ & $\mathrm{X}$ & $\mathrm{X}$ & $\mathrm{X}$ & $\mathrm{X}$ & $\mathrm{X}$ & $\mathrm{V}$ \\
\hline $\mathrm{Ti}$ & $\mathrm{X}$ & $\mathrm{V}$ & $\mathrm{V}$ & $\mathrm{X}$ & $\mathrm{V}$ & $\mathrm{V}$ \\
\hline $\mathrm{V}$ & $\mathrm{V}$ & $\mathrm{V}$ & $\mathrm{V}$ & $\mathrm{V}$ & $\mathrm{V}$ & $\mathrm{X}$ \\
\hline $\mathrm{Zn}$ & $\mathrm{V}$ & $\mathrm{V}$ & $\mathrm{V}$ & $\mathrm{X}$ & $\mathrm{V}$ & \\
\hline
\end{tabular}




\section{Supplementary Material 3: Results of statistical tests comparing the concentrations of metals between tributaries.}

The green "V" show the significant differences between the concentrations of metal measured in the total and residual fractions $(\mathrm{p}<0.05)$ and the red " $\mathrm{X}$ " for those that show no significant differences.

\begin{tabular}{|c|c|c|c|c|c|c|}
\hline \multirow[b]{2}{*}{ Elements } & \multicolumn{3}{|c|}{ Total fraction } & \multicolumn{3}{|c|}{ Non-reactive fraction } \\
\hline & $\begin{array}{l}\text { Arve } v s \\
\text { Fier River }\end{array}$ & $\begin{array}{c}\text { Arve vs Guiers } \\
\text { River }\end{array}$ & $\begin{array}{c}\text { Fier vs Guiers } \\
\text { River }\end{array}$ & $\begin{array}{l}\text { Arve vs Fier } \\
\text { River }\end{array}$ & $\begin{array}{c}\text { Arve vs } \\
\text { Guiers River }\end{array}$ & $\begin{array}{c}\text { Fier vs Guiers } \\
\text { River }\end{array}$ \\
\hline $\mathrm{Al}$ & $\mathrm{V}$ & $\mathrm{V}$ & $\mathrm{X}$ & $\mathrm{V}$ & $\mathrm{V}$ & $\mathrm{X}$ \\
\hline As & $\mathrm{V}$ & $\mathrm{V}$ & $\mathrm{V}$ & $X$ & $X$ & $X$ \\
\hline $\mathrm{Ba}$ & $\mathrm{V}$ & V & $\mathrm{x}$ & V & V & $\mathrm{x}$ \\
\hline $\mathrm{Cd}$ & $x$ & $\mathrm{~V}$ & $\mathrm{~V}$ & $\mathrm{X}$ & V & V \\
\hline Co & $x$ & $X$ & $X$ & $X$ & $X$ & $X$ \\
\hline $\mathrm{Cr}$ & $\mathrm{V}$ & $x$ & $\mathrm{~V}$ & $\mathrm{~V}$ & $\mathrm{x}$ & $\mathrm{V}$ \\
\hline $\mathrm{Cu}$ & $\mathrm{x}$ & $x$ & $\mathrm{x}$ & $\mathrm{x}$ & $\mathrm{x}$ & $\mathrm{x}$ \\
\hline $\mathrm{Fe}$ & $\mathrm{x}$ & $\mathrm{X}$ & $\mathrm{X}$ & $\mathrm{X}$ & $\mathrm{X}$ & $\mathrm{V}$ \\
\hline $\mathrm{Li}$ & $x$ & $\mathrm{~V}$ & $\mathrm{~V}$ & $\mathrm{X}$ & $\mathrm{V}$ & $\mathrm{V}$ \\
\hline $\mathrm{Mg}$ & $\mathrm{X}$ & $\mathrm{V}$ & $\mathrm{V}$ & $x$ & $\mathrm{~V}$ & $\mathrm{~V}$ \\
\hline $\mathrm{Mn}$ & $\mathrm{x}$ & $X$ & $\mathrm{~V}$ & $X$ & $X$ & $X$ \\
\hline $\mathrm{Ni}$ & $\mathrm{V}$ & $\mathrm{V}$ & $\mathrm{V}$ & $\mathrm{V}$ & $\mathrm{V}$ & $\mathrm{V}$ \\
\hline $\mathrm{Pb}$ & $X$ & $X$ & $X$ & $x$ & $\mathrm{~V}$ & $\mathrm{~V}$ \\
\hline $\mathrm{Sr}$ & $x$ & $x$ & $x$ & $x$ & $x$ & $x$ \\
\hline $\mathrm{Ti}$ & $X$ & V & $\mathrm{V}$ & $X$ & V & V \\
\hline $\mathrm{V}$ & $X$ & $X$ & $\mathrm{~V}$ & $x$ & $X$ & $\mathrm{~V}$ \\
\hline $\mathrm{Zn}$ & $X$ & $x$ & $X$ & $x$ & $x$ & $x$ \\
\hline
\end{tabular}

Generally, among the three sources, the lowest concentrations in the total fraction for most of the metals, such as $\mathrm{Al}, \mathrm{Ba}, \mathrm{Cd}, \mathrm{Cr}, \mathrm{Li}, \mathrm{Mg}, \mathrm{Ni}$ and $\mathrm{Ti}$, were measured in Guiers samples. The highest mean concentrations were found in the Arve River for $\mathrm{Al}\left(47.5 \pm 4.5 \mathrm{~g} \mathrm{~kg}^{-1}\right)$, As $\left(15.4 \pm 6.7 \mathrm{mg} \mathrm{kg}^{-1}\right)$ and Ba $\left(276 \pm 14 \mathrm{mg} \mathrm{kg}^{-1}\right)$, and in the Fier River for $\mathrm{Cr}$ and Ni concentrations $\left(72.5 \pm 17.2 \mathrm{mg} \mathrm{kg}^{-1}\right.$ and $43.1 \pm$ $4.5 \mathrm{mg} \mathrm{kg}^{-1}$, respectively). Total concentrations for $\mathrm{Cd}, \mathrm{Li}, \mathrm{Mg}$ and $\mathrm{Ti}$ are significantly different between the Guiers and Arve and between the Guiers and Fier but not significantly different between the Arve and Fier Rivers. Concerning the other metals ( $\mathrm{Co}, \mathrm{Cu}, \mathrm{Fe}, \mathrm{Mn}, \mathrm{Pb}, \mathrm{Sr}, \mathrm{V}$ and $\mathrm{Zn}$ ), the total concentrations do not display significant differences between the three tributaries.

In the non-reactive fraction, the Guiers River had the lowest concentrations for the same metals ( $\mathrm{Al}$, $\mathrm{Ba}, \mathrm{Cd}, \mathrm{Cr}, \mathrm{Li}, \mathrm{Mg}, \mathrm{Ni}$ and $\mathrm{Ti}$ ) as for the total fraction, except for $\mathrm{Pb}$. Concentrations of $\mathrm{Pb}$ in the Guiers River were significantly lower from the concentrations in the other two tributaries. The highest mean concentrations in the non-reactive fraction were found in the Arve River for $\mathrm{Al}(45.0 \pm 3.8$ $\left.\mathrm{g} \mathrm{kg-}^{1}\right)$, As $\left(12.2 \pm 7.2 \mathrm{mg} \mathrm{kg}^{-1}\right)$ and $\mathrm{Ba}\left(224 \pm 10 \mathrm{mg} \mathrm{kg}^{-1}\right)$ and in the Fier River for $\mathrm{Cr}(65.2 \pm 17.1$ $\left.\mathrm{mg} \mathrm{kg}^{-1}\right)$ and $\mathrm{Ni}\left(31.5 \pm 3.7 \mathrm{mg} \mathrm{kg}^{-1}\right)$, this following the same pattern as for the total fraction. For $\mathrm{Cd}$, $\mathrm{Cu}, \mathrm{Fe}, \mathrm{Li}, \mathrm{Mg}, \mathrm{Pb}$, Ti and $\mathrm{V}$, the concentrations in the non-reactive fraction were significantly different between the Guiers and Arve Rivers and between the Guiers and Fier Rivers but not 
significantly different between the Arve and Fier Rivers. There were no significant differences in concentrations of $\mathrm{Co}, \mathrm{Mn}, \mathrm{Sr}$ and $\mathrm{Zn}$ between the three tributaries. 
Supplementary Material 4: The enrichment factor (EF) values and standard deviation (SD) associated obtained for selected trace and major elements in SPM of the Rhône River.

\begin{tabular}{|c|c|c|c|c|c|}
\hline Matrix & Elements & $\begin{array}{c}\text { EF } \\
\text { (study period) }\end{array}$ & SD & River systems & References \\
\hline \multirow{6}{*}{ SPM } & $\mathrm{Ba}$ & 1.02 & 0.16 & & \\
\cline { 2 - 4 } & $\mathrm{V}$ & 1.15 & 0.12 & \multirow{3}{*}{ Rhône River } & \multirow{2}{*}{ Ollivier et al (2011) } \\
\cline { 2 - 4 } & $\mathrm{Ni}$ & 1.47 & 0.3 & & \\
\cline { 2 - 4 } & $\mathrm{Pb}$ & 3.89 & 1.03 & & \\
\cline { 2 - 4 } & $\mathrm{Cd}$ & 2.24 & 1.08 & & \\
\cline { 2 - 4 } & $\mathrm{Zn}$ & 3.32 & 0.92 & & \\
\hline
\end{tabular}

The EF was calculated according to following equation (according to Ollivier et al. (2011)):

$\mathrm{EF}=\left(\mathrm{C}_{\mathrm{ie}} /[\mathrm{Al}]_{\mathrm{e}}\right) /\left(\mathrm{C}_{\mathrm{ir}} /[\mathrm{Al}]_{\mathrm{r}}\right)$

where $\mathrm{C}_{\mathrm{ie}}$ is the concentration of element $\mathrm{i}$ in SPM/sediment samples, $[\mathrm{Al}]_{\mathrm{e}}$ is the aluminium (Al) concentration in SPM samples, $C_{i r}$ is the concentration of element $i$ in a reference sample and $[A I]_{r}$ is the $\mathrm{Al}$ concentration in a reference sample. Concentrations of $\mathrm{Al}$ are used as reference since they are not influenced by anthropogenic inputs (except for sites with bauxite extraction). In addition, aluminium is used as a particle size proxy, which allows the values to be compared without introducing the bias of grain size variation. 
Supplementary Material 5: Comparison of uncertainties (expressed as 95\% confidence interval: CI95\%) associated with the mixing model output for the geochemical tracers selected in the total fraction with uncertainties calculated for the geochemical tracers selected in the residual fraction for SPM from the three tributaries (Arve, Fier and Guiers Rivers).

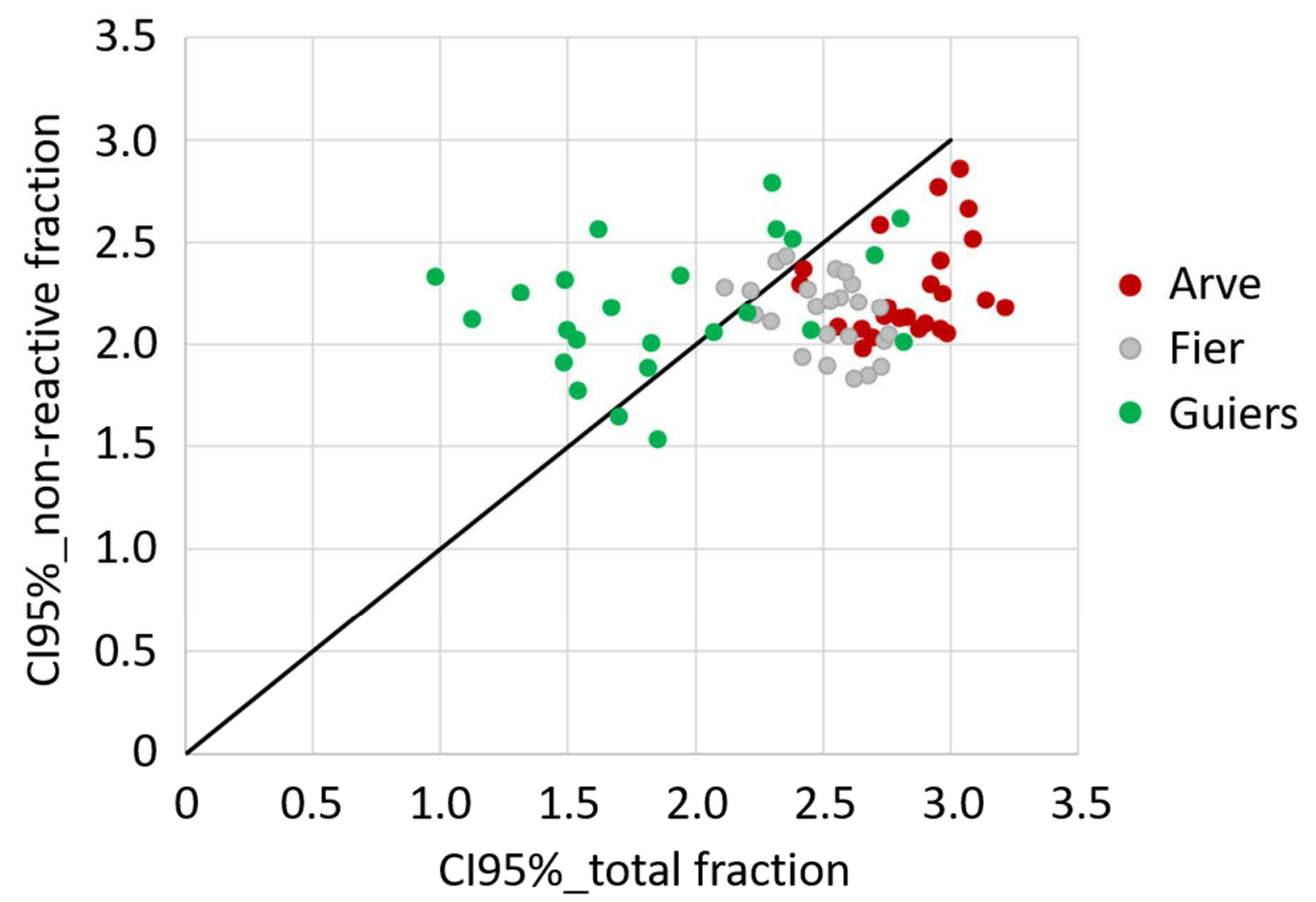

